\title{
WestVirginiaUniversity
}

THE RESEARCH REPOSITORY @ WVU

West Virginia Agricultural and Forestry Experiment

Davis College of Agriculture, Natural Resources

Station Bulletins

And Design

$1-1-1966$

\section{Hunting quality of privately owned lands in West Virginia}

Kenneth D. McIntosh

Follow this and additional works at: https://researchrepository.wvu.edu/ wv_agricultural_and_forestry_experiment_station_bulletins

\section{Digital Commons Citation}

McIntosh, Kenneth D., "Hunting quality of privately owned lands in West Virginia" (1966). West Virginia Agricultural and Forestry Experiment Station Bulletins. 539.

https://researchrepository.wvu.edu/wv_agricultural_and_forestry_experiment_station_bulletins/493 @ WVU. It has been accepted for inclusion in West Virginia Agricultural and Forestry Experiment Station Bulletins by an authorized administrator of The Research Repository @ WVU. For more information, please contact ian.harmon@mail.wvu.edu. 
West Virginia University Libraries 



\section{Hunting Quality of \\ Privately Owned Lands \\ In West Virginia}

Bulletin 539

December 1966

WEST VIRGINIA UNIVERSITY AGRICULTURAL EXPERIMENT STATION

m.

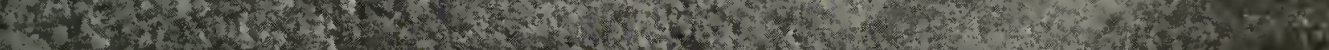

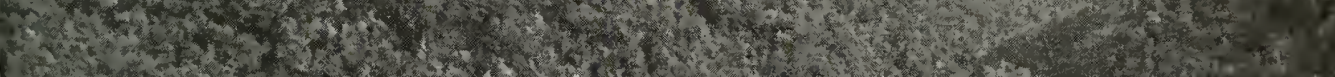

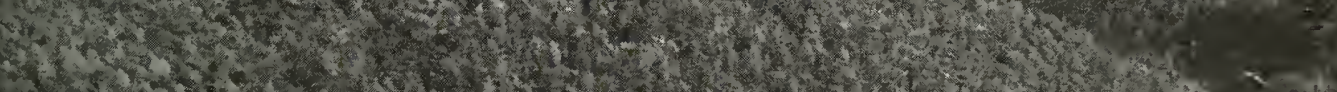

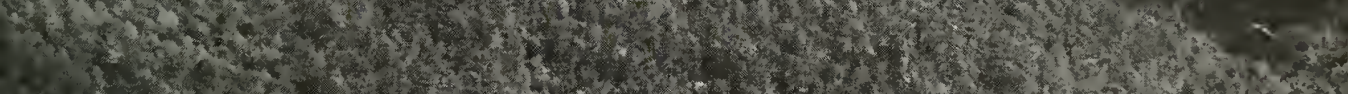

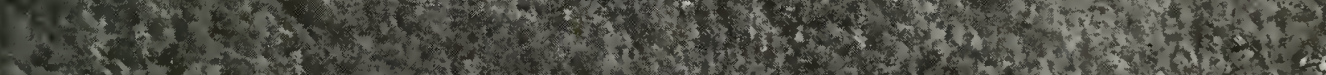

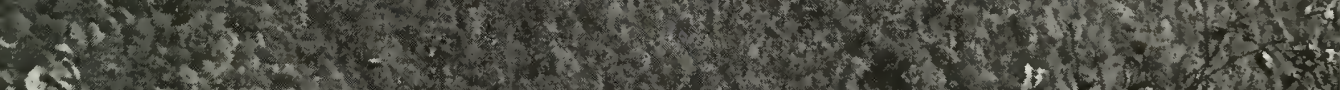

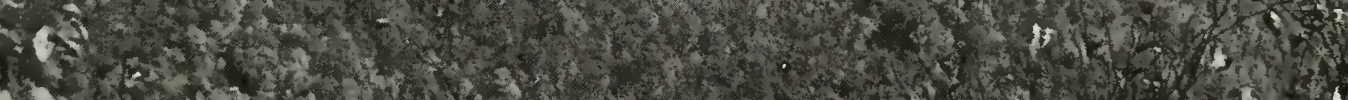

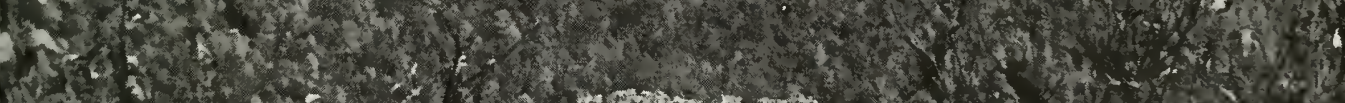

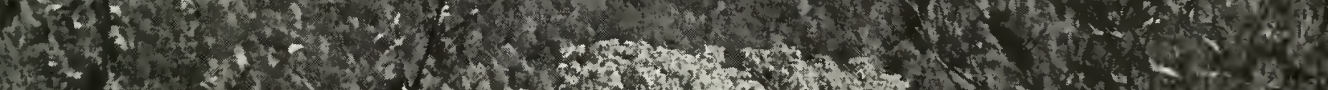

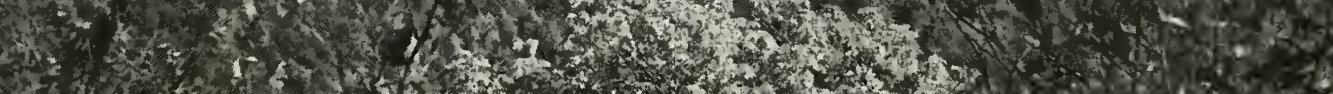

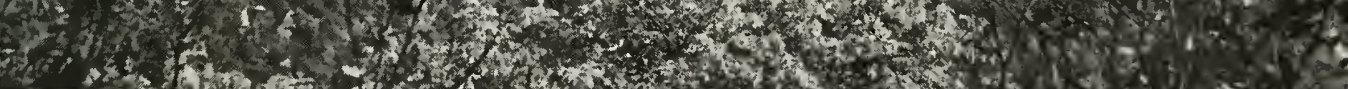

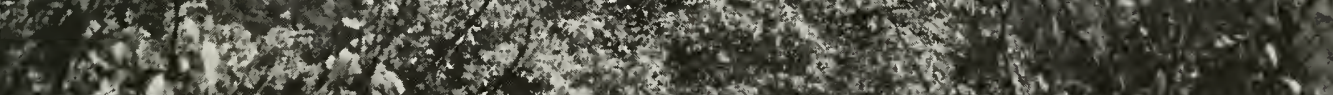

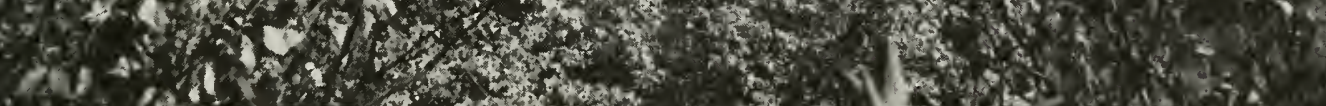
$6 a^{2}$ 
Digitized by the Internet Archive in 2010 with funding from

Lyrasis Members and Sloan Foundation 


\section{Hunting Quality of Privately Owned Lands In West Virginia}

KENNETH D. McINTOSH

West Virginia University Agricultural Experiment Station 
THE AUTHOR

Kenneth D. Mclntosh is Assistant Agricultural Economist.

Cover photo by Vic Haines

West Virginia UNIVERSITY

Agrigultural. Experiment Station

College of Agriculture and Forestry

A. H. VanLandingham, Director

MORGANTOWN 


\section{CONTENTS}

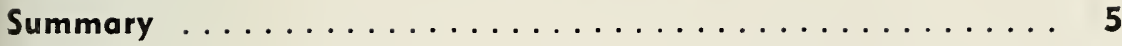

Introduction $\ldots \ldots \ldots \ldots \ldots \ldots \ldots \ldots \ldots \ldots \ldots \ldots \ldots$

Number and Kinds of Wildlife $\ldots \ldots \ldots \ldots \ldots \ldots \ldots$

Annual Kill of Wildlife ..................... 12

Forest-Open Land Ratios .................. 13

Stand-Size Classes of the Forest $\ldots \ldots \ldots \ldots \ldots \ldots \ldots, 19$

Agricultural Uses of the Land; Small Grain, Hay and Pasture . . 23

Hunting Quality and Natural Succession in Northwest

West Virginia ...................... 25

Population Characteristics $\ldots \ldots \ldots \ldots \ldots \ldots \ldots \ldots .27$

Quality Evaluations by Landowners ............. 30

Results of Landowner Quality Evaluations ........... 33

Statistical Test of Quality Evaluations $\ldots \ldots \ldots \ldots \ldots \ldots 41$

Farm and Non-Farm Quality Evaluations ........... 44

Statistical Test of Differences Between Farm and Non-Farm Quality Ratings 



\section{SUMMARY}

Statewide, the quality of privately owned hunting lands is relatively low for most kinds of wildlife. This situation is due largely to natural succession on large acreages of land that have been abandoned for farming purposes. The rate of decline in farm land increased sharply over the period 1950-1959 with an accompanying increase in land classified as forest and woodland, a process which has "closed-up" and gradually destroyed the habitat for many kinds of wildlife. The process of natural succession is still occurring and, as more land reverts to forest and woodland, the wildlife habitat will undoubtedly deteriorate further.

Landowner evaluations of hunting quality are in substantial agreement with the conclusion drawn from secondary information, namely, hunting quality on privately owned land is relatively low when considering the entire State. However, these landowner ratings also indicate considerable variation in quality among regions. The Eastern region has the highest quality hunting lands for deer, bear, wild turkey, rabbit, ruffed grouse, quail, and groundhog. The Northwestern region has the highest quality hunting lands for squirrel and raccoon. The Southern region has extremely low quality hunting lands for all kinds of wildlife. These differences among regions and among counties are statistically significant. It would appear that the more favorable situation in the Eastern region is due to a combination of factors such as low population densities, relatively smaller landholdings, more favorable physical environment in the form of vegetation for food and cover, and a large proportion of land in agricultural uses such as row crops, small grains, hay and pasture.

In view of its location relative to the large metropolitan areas in eastern United States, and its relatively higher quality hunting lands, the Eastern region currently offers the best potential of any area in the State for income and employment opportunities through the marketing of hunting rights. At the same time it will require considerable resources to develop this opportunity.

From the standpoint of private landowner interest, there are three major supply problems which need resolving before hunting can be expected to add substantially to future income and employment opportunities. These are: habitat deterioration through natural succession, increasing acreage of publicly owned or leased hunting lands that can be used by hunters free of charge, and the widespread prevalence of antihunting-fee attitudes among private landowners. 



\section{Hunting Quality of Privately Owned Lands In West Virginia}

KENNETH D. MaINTOSH

N RECENT YEARS considerable interest has been expressed in the outdoor recreational potential of West Virginia. Such interest has been manifested in a multitude of written and oral reports from various State, federal, and private agencies. In general these reports have been quite optimistic about our recreational opportunities and, either explicitly or implicitly, outcloor recreation has been assigned a major role in the generation of future income and employment.

However, outdoor recreation is a phrase which encompasses a broad range of activities from the very simple act of walking to the highly complex operations of a commercial ski resort. Each activity is relatively unique in its land, labor, and capital requirements, and in the experience and skill required by participants. It is these very basic supply and demand requirements that logically prevent an aggregation of very different activities. Thus, it is not very meaningful to generalize about our "outcloor recreational potential" on the basis of one or two activities. Perhaps it would be best to say that among all activities there are some which appear to offer relatively good opportunities, and there are some which appear to offer relatively poor opportunities. Regardless of one's intuition or vested interest, a certain amount of basic supply and demand information is needed for each of several activities before our total outdoor recreational potential can be adequately assessed.

Among the many recreational activities, it has been suggested quite often that hunting represents an employment and income opportunity for private landowners. As an enterprise for farmers or other private owners of land, hunting has certain advantages when compared to other recreational enterprises: landowners already have the basic requirement of land; labor requirements are relatively low and few specialized talents are necessary; it fits in relatively well with other farm enterprises; and it generally requires lower capital requirements. 
Landowners who choose to market hunting rights on their land have several alternatives. They can (1) establish commercial hunting preserves, (2) lease hunting rights to hunting clubs, (3) lease hunting rights to individuals, (4) convert their homes to hunting lodges during hunting season, or (5) assess hunting fees on individual hunters. Thus, if supply and demand conditions were favorable, private landowners would be in a position to transform what has been a free service (free entry to hunt on privately owned land) into a marketable one with value.

The ability of private landowners to earn annual income from the marketing of hunting rights depends upon the combined influence of supply and demand forces. However, if it is assumed that there is a demand, which is unchanging over the period of time under consideration, there are supply forces which will affect the income potential from hunting. Chief among these factors is the hunting quality of privately owned lands, the supply of free hunting lands, and landowner attitudes about the assessment of hunting fees.

Hunting land of good quality is not something which just naturally occurs where there are trees. The deliberate action of man is required in order to have high quality hunting lands in West Virginia, or elsewhere in many areas of the United States. In many instances species of wildlife must be introduced into an area; there must be a physical environment that furnishes adequate food and protection; and finally, man must take action to prevent overharvesting of the game, damage from dogs, harvesting out of season, and destruction of the habitat through such things as uninterrupted natural succession, forest fires, and adverse lumbering practices. Furthermore, the creation of a desirable physical environment for hunting, and the restraining of certain acts of man is not something which can be done once and then forgotten. As noted in the Outdoor Recreation Resources Review Commission's Study Report 6, (henceforth referred to as ORRRC 6) :

The maintenance of game habitat in suitable variety, size, and location is the most crucial factor in the provision for the future of a reasonable supply of
huntable game on wildlands. 1

Consistent management of the plantlife for provision of food and protective cover is required to maintain high quality hunting lands, once established. For example, habitat must be managed to prevent extensive stands of sawtimber with no breaks; den and mast trees must be retained for certain wildlife; young sprouts and seedlings must be available for

1 Hunting in the United States-Its Present and Future Role, Outdoor Recreation Resources Review Commission, Study Report Number 6 (Washington: Government Printing
Office, 1962), p. 24 . 
food for certain species; and for many of the small game animals the "edge" must be retained for food, nesting, cover, and protection. ${ }^{2}$

What is the quality for privately owned hunting lands in West Virginia? Based on available information, it appears that the quality of hunting lands in most areas of the State is not very good. ${ }^{3}$ Furthermore, if current land use trends continue, it seems likely that the quality will deteriorate further.

If the hunting quality on privately owned land is relatively poor, hunters will be encouraged to pursue their sport elsewhere. Further, low quality hunting land places in jeopardy the ability to capture monetary benefits from the marketing of hunting rights. Hunting quality on State owned or leased public hunting areas is relatively good because of wildlife management practices that are followed on these lands. Empirically, however, we have very little information on the hunting quality of privately owned lands. This lack of supporting data on private lands assumes even greater significance when ownership of land is considered. Over 90 per cent of the land in West Virginia is privately owned.

Considering the importance of quality on the potential income and employment that might be derived from hunting, a research project was undertaken in the summer of 1965 to determine hunting quality of privately owned lands. This research effort included an analysis of data collected from a sample of West Virginia landowners in 13 randomly chosen counties. This bulletin is the final report of the project.

2For some interesting discussions of wildlife habitat requirements see:

Wallace L. Anderson, Making Land Produce Useful Wildlife. Soil Conservation Service, United States Department of Agriculture, Farmers Bulletin No. 2035 (Washington: Government Printing Office, 1961).

Cooperative Wildlife Management on Virginia National Forests. Report by the Commission of Game and Inland Fisheries, The George Washington National Forest and The Jefferson National Forest, June, 1963.

H. G. Uhlig, The Gray Squirrel: Its Life History, Ecology, and Population Characteristics in West Virginia, West Virginia Department of Natural Resonrces, Final Report of Project 31-R (Charleston: West Virginia Department of Natural Resources, 1955).

Charles O. Handley, "Feeding Habits of the Bobwhite Quail," West Virginia Conservation, Vol. XXVII1 (October, 1964), pp. 29-32.

Russell A. Hill, "Try Grouse Hunting For A Change of Pace," West Virginia Con. servation, Vol. XXVIII (October, 1964), pp. 2-5.

T. S. Sanford, "The Bear Facts," West Virginia Conservation, Vol. XXIX (October, 1965), pp. 25-27.

W. R. DeGarmo and John Gill, West Virqinia White-Tails, Division of Game, Conservation Commission of West Virginia, Bulletin No. 4 (Charleston: Mathews Printing and Lithographing Company, 1958).

Charles Shick, Wildtife: An Extra Gift From the Land, Cooperative Extension Service, Michigan State University, Extension Folder F-280 (East Lansing: Michigan State University. 1963).

3The aggregate measures used in this report, as indicators of quality hunting land, have been reviewed by Dr. Robert L. Smith, Wildlife Management Specialist, Division of Forestry, Weat Virginia University, Morgantown, West Virginia. 


\section{NUMBER AND KINDS OF WILDLIFE}

The number and kinds of wildlife available for hunting is a partial measure of quality hunting lands. According to the 1965 West Virginia hunting regulations there are 14 kinds of wildlife for which hunting seasons have been established. ${ }^{\star}$ These are squirrel, ruffed grouse, wild turkey, quail, ring-necked pheasant, cottontail rabbit, varying hare, raccoon, black bear, mourning dove, woodcock, ducks, geese, and deer. However, when speaking of game animals and birds that are available in sufficient numbers to provicle satisfactory hunting for a significant number of hunters, only five of these would qualify, namely squirrel, deer, rabbit, ruffed grouse, and wild turkey.

Preliminary data obtained in a sample survey indicate that the 10 most actively sought wildlife by West Virginia hunters are, in order of importance, squirrel, deer, rabbit, ruffed grouse, wild turkey, groundhog, raccoon, quail, pheasant, and bear. ${ }^{5}$

Among the 10 most widely hunted wildlife, bear, pheasant, quail, and, to some extent, wild turkey are not very plentiful. Aggregate information on the pheasant and quail populations is not available, but it is common knowledge among hunters that there are relatively few of either in the State when compared with other states. This is partially substantiated by the fact that only 9 per cent of West Virginia hunters indicate that they hunt either quail or pheasant. Almost certainly these percentages would be higher if there were a greater supply of pheasant and quail. The ORRRG 6 report noted the lack of pheasant in

4West Virginia Hunting-Trapping Regulations, 1965-1966, West Virginia Department of Natural Resources (Charleston: West Virginia Department of Natural Resources, 1965),
pp. 1-2.

5In a randomly drawn sample of West Virginia hunters (August, 1965) each respondent was asked what kinds of wildlife he hunted for in West Virginia. The following tabulation
is a distribution of the responses:

\begin{tabular}{lrc}
\hline \hline Kind of Wildlife & Number of Hunters & Per Cent of all Hunters \\
\hline Squirrel & 328 & 92.1 \\
Deer & 232 & 65.2 \\
Rabbit & 222 & 62.4 \\
Ruffed Grouse & 129 & 36.2 \\
Wild Turkey & 80 & 22.5 \\
Groundhog & 71 & 19.9 \\
Raccoon & 47 & 13.2 \\
Quail & 33 & 9.3 \\
Pheasant & 33 & 9.3 \\
Bear & 23 & 6.5 \\
Fox & 6 & 1.7 \\
Duck & 3 & 0.8 \\
Opossum & 1 & 0.3 \\
\hline Total Hunters Interviewed & 356 & \\
\hline
\end{tabular}


Appalachia in the following manner:

From the information schedule responded to by State game agencies it was found, for example, that the ring-necked pheasant is the most abundant upland game bird of 22 states and is the most popular with hunters in 15 of them, but it falls into neither category in the Southeast, Appalachian, Delta and Southwest Regions. ${ }^{6}$

Data on deer, black bear, and wild turkey populations are available from the Big Game Inventories published by the U. S. Department of the Interior. ${ }^{7}$ In 1959 it was estimated that there were 75,000 deer, 9,000 wild turkey, and 500 black bear in the State. Personnel in the West Virginia Department of Natural Resources indicate that there has been a slight increase in the numbers of wild turkey and deer since 1959 but the bear population has remained constant. ${ }^{8}$ Assuming that the 1959 inventory of big game species is reasonably accurate, the State ranks 17th among 37 states reporting deer, 12 th among 26 states reporting wild turkey, and 15th among 23 states reporting black bear.

Squirrel, rabbit, ruffed grouse, groundhog, and raccoon are found throughout the State, but there are no statewide data on the populations of any of these species. Smith reports that the squirrel population has steadily decreased since the heavy timber cutting between 1890-1920 and the chestnut blight of 1920 's. ${ }^{9}$ In spite of this decline more West Virginia hunters hunt squirrel than any other kind of wildlife. In a random sample of 356 hunters, approximately 92 per cent hunt squirrel, 65 per cent hunt deer, 62 per cent hunt rabbit, 36 per cent hunt ruffed grouse, 23 per cent hunt wild turkey, and 20 per cent hunt groundhog.

If it is assumed that most hunters pursue game animals which are most abundant, thereby offering the most favorable opportunity for a successful hunting trip, it is obvious that squirrel, deer, rabbit, and ruffed grouse, are the most abundant game animals in the State. At the same time it could be concluded that there are relatively few geese, duck, bear, pheasant, and quail. If hunting quality were assessed primarily on the basis of species available and their numbers, West Virginia would not rank very high in relation to many other states.

6Hunting In the United States-Its Present and Future Role, Outdoor Recreation Resources Review Commission, Study Report Number 6 (Washington: Government Printing Office, 1962), p. 12.

7 Big Game Inventory for 1955, Fish and Wildlife Service, United States Department of the Interior, Wildlife Leaflet 387 (Washington: United States Department of the Interior, 1957 ); and, Big Game Inventory for 1959, Fish and Wildlife Service, United States Department of the Interior, Wildlife Leaflet 425 (Washington: United States Department of the Interior, 1960).

8 Sanford, op. cit., p. 26.

9Robert L. Smith, "The Gray Squirrel," West Virginia Conservation, VoI. XX1X (July, 1965), pD. 8-13. 


\section{ANNUAL KILL OF WILDLIFE}

Another incomplete measure of quality hunting lands is the number of each kind of wildlife killed over a period of time, such as a hunting season. Annual kill figures are related to such factors as species available for hunting, abundance of each and hunting pressure, hunting seasons and regulations. In turn, the species available and their abundance are related to such factors as food supply, protective covering, restocking programs, and harvesting practices.

West Virginia Department of Natural Resources maintains records on legal kills of big game animals (deer and bear) and wild turkey. Statewide clata on the annual harvesting of small game animals have not been maintained. As indicated in Tables 1, 2, and 3 the annual kill of wild turkey and bear is quite low, and, in relation to other states, the annual kill of deer is also low. ${ }^{10}$ These clata do not include wildlife illegally killed or kills made by motor vehicles, dogs, trains, etc. Nevertheless, if annual harvesting of big game animals and wild turkey is an indicator of quality hunting lands, the data lend support to the beliet that the quality of hunting lands in West Virginia is not very good.

There is also the possibility that the aggregate annual kill figures do not accurately portray the hunting quality for sub-areas of the State. As noted in Figures 1, 2, 3, and Table 4, a large proportion of the deer, bear and wild turkey are killed in the Eastern region of West Virginia. Furthermore, there is a noticeable degree of concentration by counties and species of wildlife. Each year from two-thirds to three-fourths of all the black bear are killed in Pocahontas, Randolph, and Pendleton counties (Table 3). Wild turkey is slightly more dispersed with 75 to 85 per cent of the annual kill occurring in the counties of Grant, Greenbrier, Hampshire, Hardy, Pendleton, Pocahontas, and Randolph (Table 2). Deer are heavily concentrated also with 65 to 70 per cent of the annual kill occurring in counties of Grant, Greenbrier, Hampshire, Hardy, Mineral, Pendleton, Pocahontas, Preston, Randolph, and Tucker (Table 1). These data on annual kill by county strongly suggest that the best quality hunting lands for deer, bear, and wild turkey are found in or adjacent to the high mountain counties along the eastern border of the State. At the same time the most significant gleaning from Figures 1, 2, and 3 and Tables 1, 2, and 3 is the large number of counties where there are very few, if any, bear or wild turkey and almost no deer. For these wildlife, consiclering annual kill figures only, one can infer that the overall quality of hunting lands is relatively low.

10 Big Game Inventory For 1959, Fish and Wildlife Service, United States Department of the Interior, Wildlife Leaflet 425 (Washington: United States Department of the Interior, 1960), pp. 2-4. 


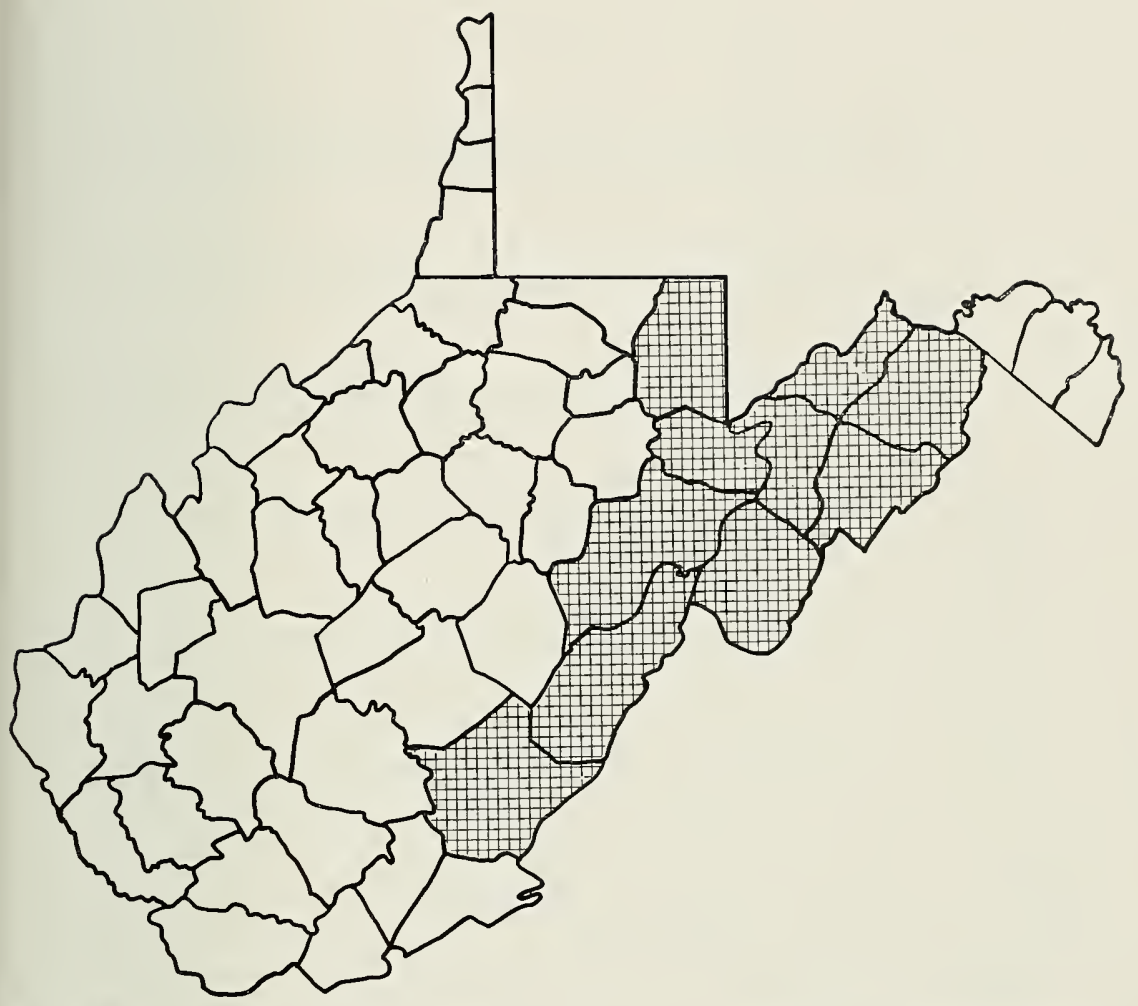

FIGURE 1. Ten Leading Counties in Annual Kill of Deer in West Virginia.

There are no aggregate clata on annual kills of small game either for the State or for individual counties. The lack of annual kill figures for these animals is also accompanied by a lack of reliable estimates on total populations. Professor Robert Smith in the Wildlife Section, Division of Forestry, West Virginia University, indicated to the writer that these wildlife are found throughout the State but with no major concentrations in any area.

\section{FOREST-OPEN LAND RATIOS}

Another general method of assessing the quality of hunting lands is the amount of forest land to open land. Open land, as defined by the United States Forest Service, is composed of cropland and pasture. ${ }^{11}$ Pasture includes what most agriculturists call permanent pasture. According to an old rule of thumb, areas which have a cover of 60 per cent forest

11Roland H. Ferguson, The Timber Resources of West Virginia, Forest Service, United States Department of Agriculture, Resource Bulletin NE-2 (Upper Darby: United States Department of Agriculture, 1964), p. 16. 


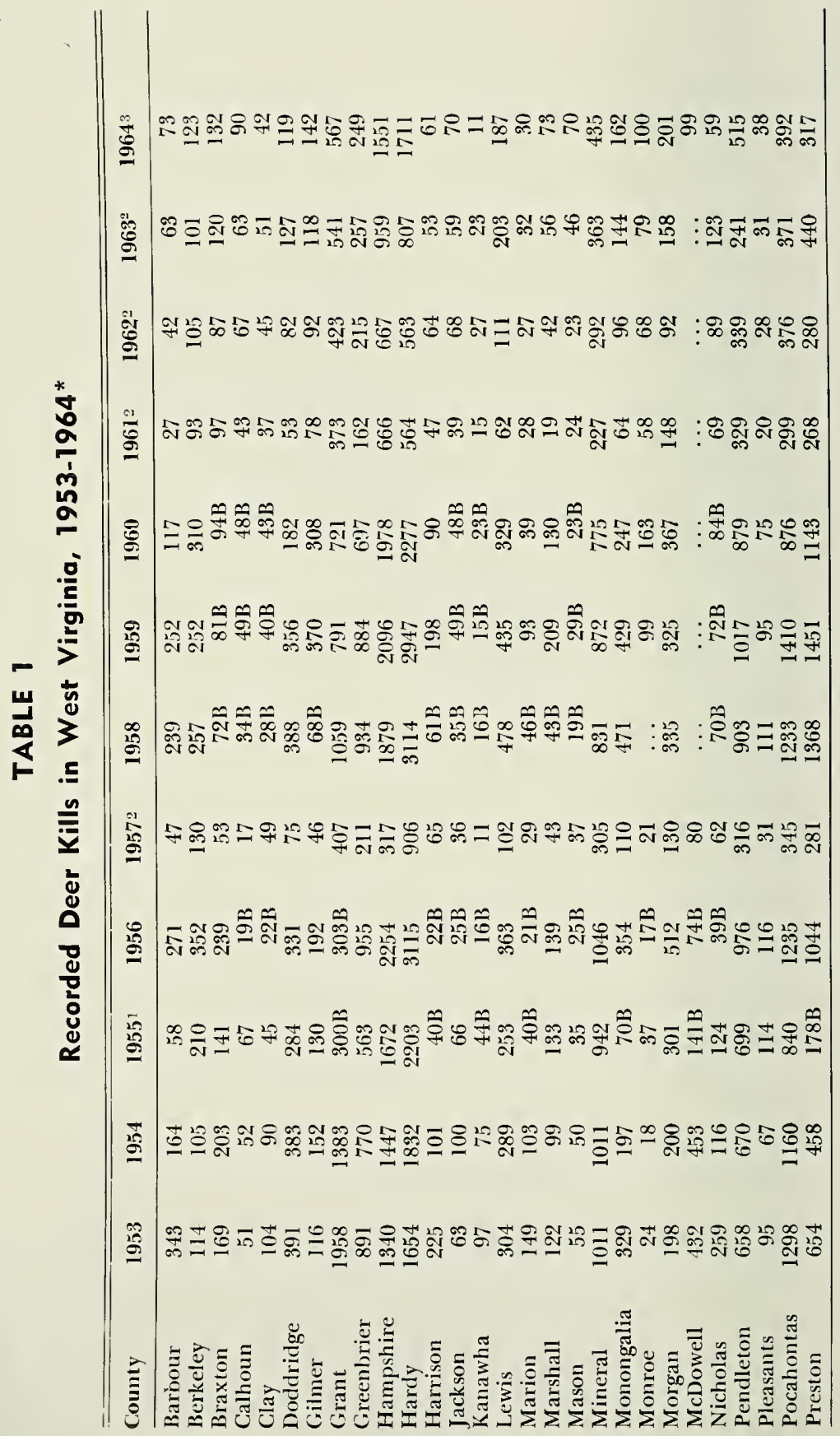




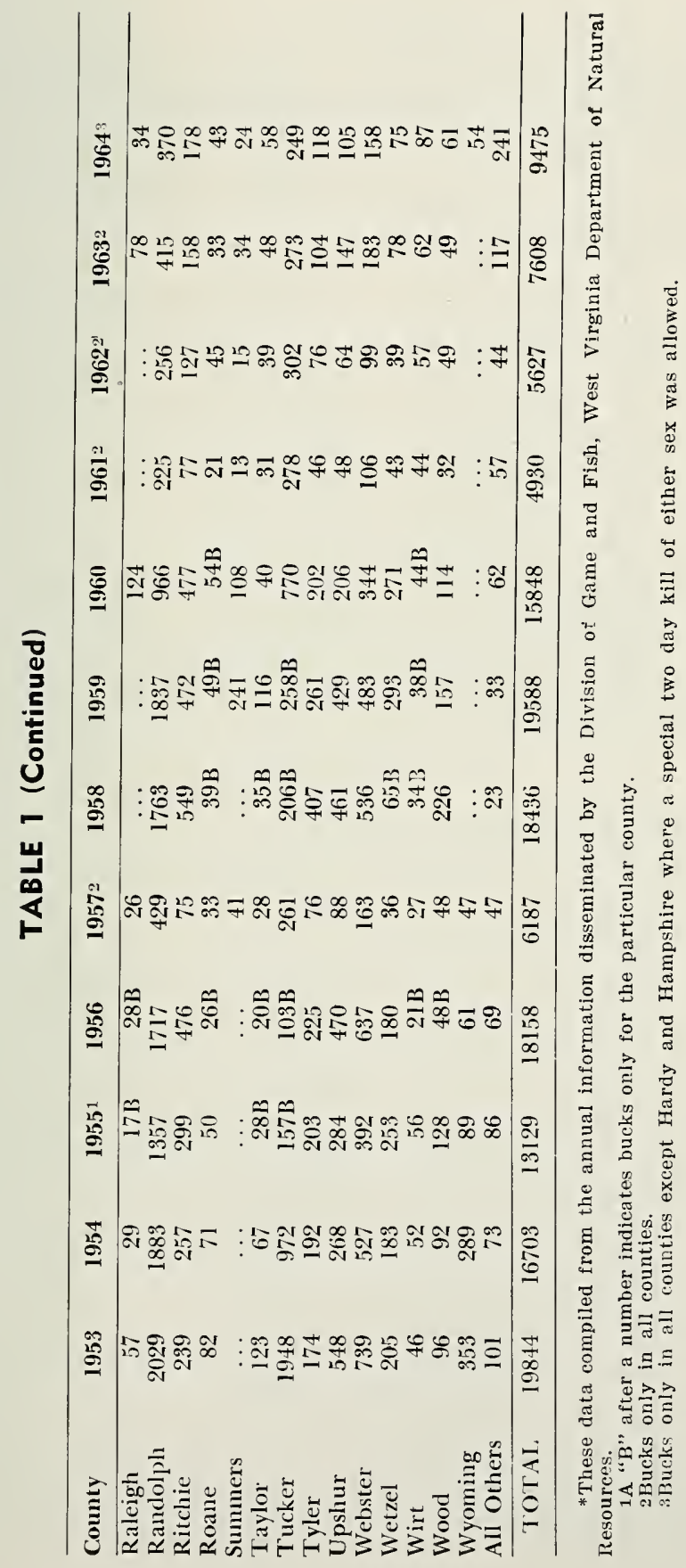




\section{TABLE 4}

Proportion of Big Game and Wild Turkey Kills Occurring in the Ten Ranking Counties of West Virginia*

\begin{tabular}{|c|c|c|c|}
\hline Year & White Tailed Deer & Wild Turkey & Black Bear \\
\hline & \multicolumn{3}{|c|}{ Per Cent } \\
\hline $\begin{array}{l}1951 \\
1952\end{array}$ & $\begin{array}{l}77 \\
75\end{array}$ & 97 & $\begin{array}{r}95 \\
100\end{array}$ \\
\hline 1953 & $\begin{array}{l}75 \\
68\end{array}$ & $\begin{array}{l}97 \\
92\end{array}$ & $\begin{array}{r}100 \\
99\end{array}$ \\
\hline 1954 & $\begin{array}{l}08 \\
69\end{array}$ & 92 & $\begin{array}{r}99 \\
100\end{array}$ \\
\hline 1955 & 68 & $\begin{array}{l}94 \\
92\end{array}$ & $\begin{array}{l}100 \\
100\end{array}$ \\
\hline 1956 & 70 & 94 & $\begin{array}{l}100 \\
100\end{array}$ \\
\hline 1957 & 69 & 92 & $\begin{array}{l}100 \\
100\end{array}$ \\
\hline 1958 & 72 & 92 & 95 \\
\hline 1959 & 69 & 90 & 100 \\
\hline 1960 & 70 & 87 & 100 \\
\hline 1961 & 69 & 91 & 95 \\
\hline 1962 & 66 & 88 & 100 \\
\hline 1963 & 64 & 2 & 100 \\
\hline 1964 & 67 & $2^{\prime}$ & 2 \\
\hline
\end{tabular}

*Ranking counties for deer include: Grant, Greenbrier, Hampshire, Hardy, Mineral, Pendloston, Randolph, and Tucker. Ranking counties for wild turkey include: Grant, Greenbrier, Hampshire, Hardy, Mineral, Morgan, Pendleton, Pocahon, Hardy, Mon roe, Pendleton, Pocahontas, Randolph, Tucker, and Webster.

iNine ranking counties.

2Data not available.

and 40 per cent open land generally provide an adequate physical base for quality hunting lands. DeGarmo and Gill indicate that deer do exceedingly well where 64 per cent of the land is forested and 36 per cent is open land. ${ }^{12}$

If we use a forest-open land ratio of $60-40$ as a guideline, it can be tested empirically at the state and county level by noting the detailed information on land use contained in the Census of Agriculture and the 1961 United States Forest Service Survey of West Virginia. When the data from these two sources are assembled it is noted that approximately 75 per cent of the total land area in West Virginia is classified as forest (Table 5). Strict adherence to a $60-40$ ratio would therefore lead to the conclusion that the quality of hunting lands, statewide, is relatively low due to the extensive forest cover relative to open land.

Among the counties a relaxing of the $60-40$ ratio by 5 percentage points, plus or minus, would still eliminate all but five counties (Barbour, Jackson, Marshall, Roane, and Upshur) from consideration as relatively high quality hunting areas. Furthermore, not one of these five counties is among the top 20 counties in the annual kill of bear, wild turkey, or deer. 


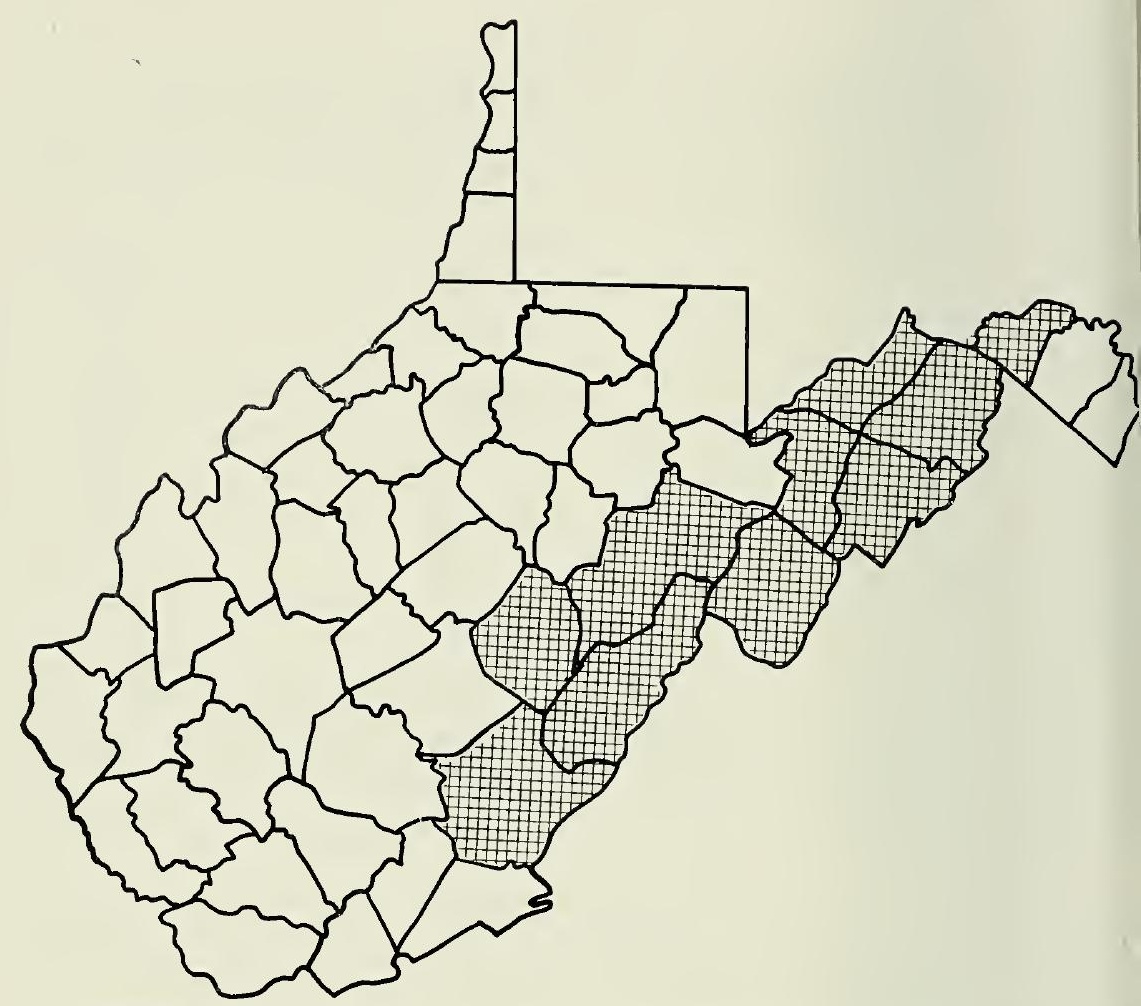

FIGURE 2. Ten Leading Counties in Annual Kill of Wild Turkey in

As it turns out, if we compare Figures 1, 2, and 3 with Table 5, it is evident that the counties with largest annual kills of deer, bear, and wild turkey, presumably reflecting quality hunting lands, are those where the forest cover is between $70-85$ per cent. Further, it is noted that about 15-20 per cent of the land in these counties is classified as cropland and pasture (Table 5). The five ranking counties in annual deer kill average approximately 72 per cent forest and 23 per cent open land (Table 6). These data must be interpreted with a certain degree of caution. Desirable habitat for big game and wild turkey is not the same as that for small game animals such as rabbit, quail, and pheasant. As pointed out by Kozicky, ${ }^{13}$ high quality hunting land for these wildlife is related to the edge, and aggregate data on forest-to-open land ratios can and do cover up a lot of edge.

13Edward L. Kozicky, "Plant Cover Management on Shooting Preserves," Speech given at the North American Game Breeders and Shooting Preserve Association Meeting, Dallas.
Texas, January $13-15,1963$. 


\section{STAND-SIZE CLASSES OF THE FORESTS}

The quality of hunting lands is affected also by the species of trees, stand-size classes, and degree of stocking in an area. For instance, a pure stand of mature pine trees in an area that is considered to be 100 per cent stocked provides a poor habitat for food but at the same time it provides excellent protection from man and weather. As pointed out in ORRRC 6 :

There is a general observation that unbroken stands of a single species are wildlife "deserts." This is true at least in the sense that mixed species stands provide a variety of food and cover that is impossible in pure stands.14

Lands which are only 10-25 per cent stocked with trees may provide an adequate food supply but they generally have insufficient protection cover for wildlife, especially big game and wild turkey.

For most species of wildlife a forest that is composed of larger sawtimber and poletimber does not provide an adequate food supply for really good quality hunting lands. Wildlife numbers decrease in such areas with a consequent reduction in the hunting potential. The canopy in a forest continues to close up as the trees pass through the life cycle from seedlings-saplings-poletimber to sawtimber, and as the canopy closes the understory receives less and less sunlight for the production of small bushes, shrubs, weeds, vines, and grass. As noted in ORRRC 6:

Although most types of climax forest stands have from a few to several codominate species, and occur in several layers composed of small trees, shrubs, herbs, etc. and are far removed in characteristics from single-species stands, they are not very productive of game. This is largely because of the heavy shading that cuts down on the low vegetation that can be reached by browsing animals. The most productive landscape for wildlife is one that has a mosaic of cover types of different sorts. In general, not only does the existence of a variety of cover types increase the variety of game food, shelter, etc., but the production of "edge" or ecotone is beneficial to game. ${ }^{15}$

Thus, in an area with an extensive cover of sawtimber and poletimber, where there are few breaks or openings, high quality hunting lands would not be expected. At the present time this assumption is reasonably well supported in the southern part of the State and if the process of natural succession continues, without interruption, in northwest West Virginia the quality of hunting lands in large areas of that region will continue to deteriorate.

For sampling purposes the United States Forest Service stratifies the State into three large areas (Figure 4). Comparing the data on annual kills of deer, bear and wild turkey, Tables 1, 2, and 3, with these Forest Service subdivisions, counties with the largest annual kill are located in

1+Hunting In The Unitca States-Its Prcsent and Future Role, Outdoor Recreation Resources Review Commission, Study Report Number 6 (Washington: Government Printing Office, 1962), p. 21.

15lbid., pp. 21-22. 
TABLE 5

Forest, Cropland, and Pasture as a Proportion of Total County Area in West Virginia, 1959-1961*

\begin{tabular}{|c|c|c|c|c|c|}
\hline County & Forest & Cropland & Pasture & Cropland and & Pasture \\
\hline \multicolumn{6}{|c|}{ Per Cent ${ }^{1}$} \\
\hline Barbour & 61.6 & 14.1 & 23.0 & 37.1 & \\
\hline Berkeley & 48.0 & 30.7 & 15.3 & 46.0 & \\
\hline Boone & 92.3 & 0.7 & 0.2 & 0.9 & \\
\hline Braxton & 64.6 & 9.2 & 19.7 & 28.9 & \\
\hline Brooke & 46.0 & 13.4 & 10.4 & 23.8 & \\
\hline Cabell & 73.2 & 12.2 & 6.1 & 18.3 & \\
\hline Calhoun & 81.6 & 9.6 & 18.1 & 27.7 & \\
\hline Clay & 84.7 & 4.4 & 5.7 & 10.1 & \\
\hline Doddridge & 69.8 & 8.0 & 21.0 & 29.0 & \\
\hline Fayette & 85.1 & 5.2 & 0.8 & 6.0 & \\
\hline Gilmer & 81.7 & 9.3 & 17.4 & 26.7 & \\
\hline Grant & 73.0 & 7.5 & 18.2 & 25.7 & \\
\hline Greenbrier & 78.2 & 7.8 & 13.8 & 21.6 & \\
\hline Hampshire & 69.7 & 15.9 & 6.2 & 22.1 & \\
\hline Hancock & 64.2 & 11.5 & 9.7 & 21.2 & \\
\hline Hardy & 77.2 & 9.2 & 12.1 & 21.3 & \\
\hline Harrison & 42.6 & 18.2 & 30.1 & 48.3 & \\
\hline Jackson & 63.4 & 18.4 & 16.9 & 35.3 & \\
\hline Jefferson & 24.1 & 49.0 & 20.4 & 69.4 & \\
\hline Kanawha & 83.6 & 3.8 & 0.9 & 4.7 & \\
\hline Lewis & 53.6 & 12.1 & 31.7 & 43.8 & \\
\hline Lincoln & 80.5 & 8.9 & 3.7 & 12.6 & \\
\hline Logan & 92.8 & 1.0 & 0.1 & 1.1 & \\
\hline McDowell & 90.5 & 0.8 & 0.2 & 1.0 & \\
\hline Marion & 64.7 & 15.2 & 10.4 & 25.6 & \\
\hline Marshall & 60.3 & 15.1 & 21.9 & 37.0 & \\
\hline Mason & 60.9 & 18.6 & 13.2 & 31.8 & \\
\hline Mercer & 72.2 & 11.3 & 8.1 & 19.4 & \\
\hline Mineral & 74.8 & 8.1 & 11.0 & 19.1 & \\
\hline Mingo & 92.7 & 2.3 & 0.3 & 2.6 & \\
\hline Monongalia & 57.6 & 15.7 & 12.4 & 28.1 & \\
\hline Monroe & 69.3 & 8.6 & 20.4 & 29.0 & \\
\hline Morgan & 77.4 & 12.9 & 3.6 & 16.5 & \\
\hline Nicholas & 83.4 & 7.1 & 3.6 & 10.7 & \\
\hline Ohio & 51.6 & 23.7 & 16.4 & 40.1 & \\
\hline Pendleton & 78.2 & 6.3 & 14.8 & 21.1 & \\
\hline Pleasants & 71.3 & 7.8 & 13.0 & 20.8 & \\
\hline Pocahontas & 79.5 & 6.4 & 8.5 & 14.9 & \\
\hline Preston & 64.4 & 16.4 & 10.2 & 26.6 & \\
\hline Putnam & 81.2 & 10.3 & 7.6 & 17.9 & \\
\hline Raleigh & 80.0 & 7.8 & 1.3 & 9.1 & \\
\hline Randolph & 84.7 & 6.6 & 6.3 & 12.9 & \\
\hline Ritchie & 68.2 & 8.1 & 19.8 & 27.9 & \\
\hline Roane & 63.7 & 16.0 & 19.0 & 35.0 & \\
\hline Summers & 75.4 & 13.7 & 9.4 & 23.1 & \\
\hline Taylor & 51.4 & 18.8 & 23.9 & 42.7 & \\
\hline Tucker & 87.7 & 5.0 & 5.6 & 10.6 & \\
\hline Tyler & 63.2 & 10.0 & 19.1 & 29.1 & \\
\hline Upshur & 58.4 & 13.5 & 23.2 & 36.7 & \\
\hline Wayne & 78.9 & 8.1 & 4.0 & 12.1 & \\
\hline
\end{tabular}

(Continued on Next Page) 


\section{TABLE 5 (Continued)}

\begin{tabular}{lcccc}
\hline \hline County & Forest & Cropland & Pasture & Cropland and Pasture \\
\hline \multirow{2}{*}{ Webster } & & & Per Cent 1 & \\
Wetzel & 89.2 & 3.2 & 0.4 & 3.6 \\
Wirt & 79.5 & 8.2 & 5.1 & 13.3 \\
Wood & 62.0 & 10.5 & 13.7 & 24.2 \\
Wyoming & 91.5 & 16.0 & 13.5 & 29.5 \\
TOTAL & 74.4 & 4.7 & 0.4 & 5.1 \\
\hline \multicolumn{1}{l}{ TOTA } & 10.1 & 10.9 & 21.0 \\
\hline
\end{tabular}

*United States Bureau of the Census. United States Census, of Agriculture: 1959, Vol. I, Part 25, Counties, West Virginia (Washington: Government Printing Office, 1961): and R. H. Ferguson, The Timber Resources of West Virginia, Forest Service, United States Department of Agriculture, Resources Bnlletin NE-2 (Upper Darby: United States Department of Agricnlture, 1964).

1The percentages do not add to 100 because special uses of land (urban, railroads, highways, airports, etc.) have been excluded.

the Northeastern geographical sampling unit. Again this area includes the high mountain counties of the State and within its boundaries National Forests account for 13 per cent of the total land area. ${ }^{16}$

According to Clarkson ${ }^{17}$ the forests in much of the Northeastern area were cut over during the period 1880-1910, a period in which West Virginia ranked very high in the annual production of harlwood lumber. After a growing period of 50-70 years, a relatively large proportion of the trees are once again in the poletimber and sawtimber stages. This is noted especially in the counties of Hardy, Pocahontas, Pendleton, Randolph, and Tucker where more than 80 per cent of the trees are classified as sawtimber or poletimber.

The forests in Southern West Virginia also contain a high proportion of poletimber and sawtimber. With the exception of Monroe and Summers counties, over three-fourths of the forest in the region is classified as poletimber and sawtimber. In Mingo, Boone, Logan, Raleigh, and Greenbrier counties over 80 per cent of the forest is poletimber and sawtimber.

In the Northwest region approximately 70 per cent of the forests is classified as poletimber and sawtimber. At the same time 30 per cent of the forest in this region is in the sapling and seedling stage, reflecting the large scale abandonment of farms during the period 1950-1959.

On the basis of stand-size class we would expect that the Northwest area would be more productive of wildlife than the other two areas. Yet when we compare annual kill figures with this tripartite division of the State, it is noted that the Northeast region ranks highest in annual kills of deer, bear, and wild turkey. $1965)$.

17 Roy B. Clarkson, Tumult on the Mountains (Parsons: McClain Printing Company. 


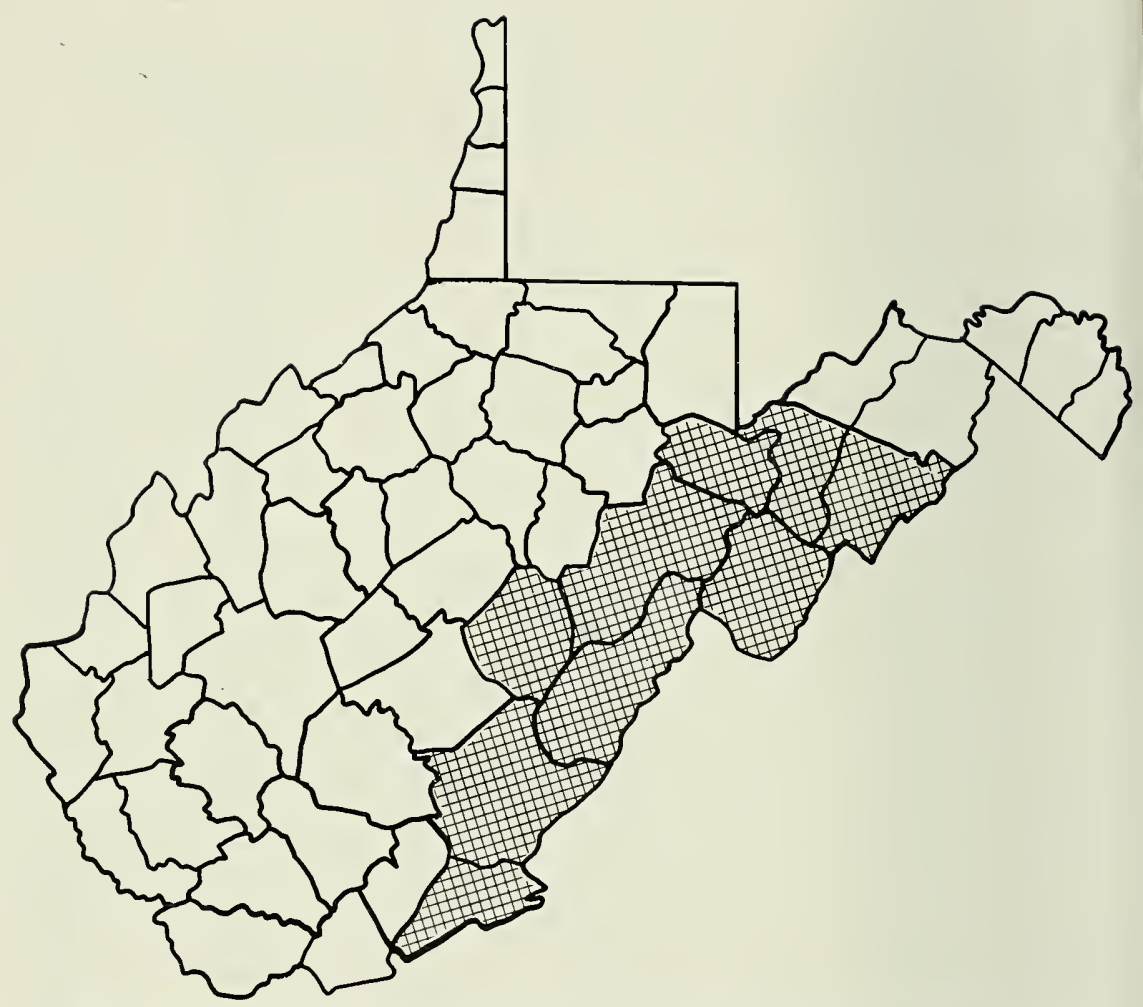

FIGURE 3. Nine Leading Counties in Annual Kill of Black Bear in West Virginia.

Among hunters it is generally known that the Southern counties of West Virginia have poor hunting lands and the annual kill figures support this view. Very few deer, bear, and wild turkey are killed in the area lying south of the Kanawha River. Thus we have two large areas of the State (Northeast and Southern), each with a large proportion of the land in forest and each with a high proportion of poletimber and sawtimber in the forest, yet in one area the annual kill data is relatively high (Northeast) and in the other (Southern) it is relatively low. The disparity appears to be related, in large measure, to the amount of nonforest land, the uses made of such land and its distribution over the landscape. In addition, the hunting quality in the Southern region is adversely affected by a large number of dogs and the widespread prevalence of poaching.

As noted earlier the extensiveness of the forest cover varies among the three regions. In the Northeast region 70 per cent of the land is 
TABLE 6

\section{Cross Comparison Between Leading Counties in Deer Kill and Proportion of Land Area in Forest, Cropland, and Pasture}

\begin{tabular}{lcccc}
\hline \hline County & Land Area & $\begin{array}{c}\text { Rank In } \\
\text { Deer Kill } \\
\mathbf{1 9 6 0 - 1 9 6 4}\end{array}$ & $\begin{array}{c}\text { Per Cent } \\
\text { Forest }\end{array}$ & $\begin{array}{c}\text { Per Cent Cropland } \\
\text { and Pasture }\end{array}$ \\
\hline Grant & 305,280 & 3 & 73.0 & 25.7 \\
Greenbrier & 656,640 & 10 & 78.2 & 21.6 \\
Hampshire & 408,960 & 2 & 69.7 & 22.1 \\
Hardy & 374,000 & 1 & 77.2 & 21.3 \\
Mineral & 211,200 & 8 & 74.8 & 19.1 \\
Pendleton & 444,800 & 4 & 78.2 & 21.1 \\
Pocahontas & 603,520 & 6 & 79.5 & 14.9 \\
Preston & 412,800 & 5 & 64.4 & 26.6 \\
Randolph & 663,040 & 7 & 84.7 & 12.9 \\
Tucker & 269,440 & 9 & 87.7 & 10.6 \\
\hline
\end{tabular}

classified as forest compared with 83 per cent in the Southern and 69 per cent in the Northwest region. Furthermore, in five of the Southern counties forest land comprises 90 per cent or more of the total land area.

In addition to the more extensive forest cover in the Southern region, individual holdings of forest land in many of these counties are relatively large; tracts of 1,000 acres or more account for a large proportion of all land. ${ }^{18}$ For instance, there are 322,600 acres in Wyoming County and, of this quantity, 186,850 acres are owned by three owners. In Fayette County there are 421,800 acres and 173,963 of these are owned by 13 owners, three of whom own a combined total of 130,000 acres. ${ }^{19}$ These relatively large, unbroken tracts of forest in the Southern region do not provide sufficient food and edge for good quality hunting lands.

Like the Southern region there is a large proportion of sawtimber and poletimber in the Northeast region. In spite of this similarity, some important differences are noted when the Northeast is contrasted with the Southern region. In the Northeast there is less of the total land in forest, the individual tracts of land are much smaller in size, and there are more breaks and edge in the form of cropland for grain, hay, and pasture.

\section{AGRICULTURAL USES OF THE LAND; SMALL GRAIN, HAY AND PASTURE}

Still another indicator of the quality of hunting lands is the agricultural uses of land in an area. Traditionally wildlife have fed upon such agricultural crops as corn, small grain, hay, pasture, and fruit trees. As

18A. Edwin Grafton, "Forest Landownership in West Virginia. Its Characteristies, Patterns and Trends" (Unpublished Master $\&$ thesis, West Virginia University, Morgantown, $1963)$, pp. 23,55 , and 69 .

19Results of a sample survey of landowners made by the author in .Iune and July, 1965. 


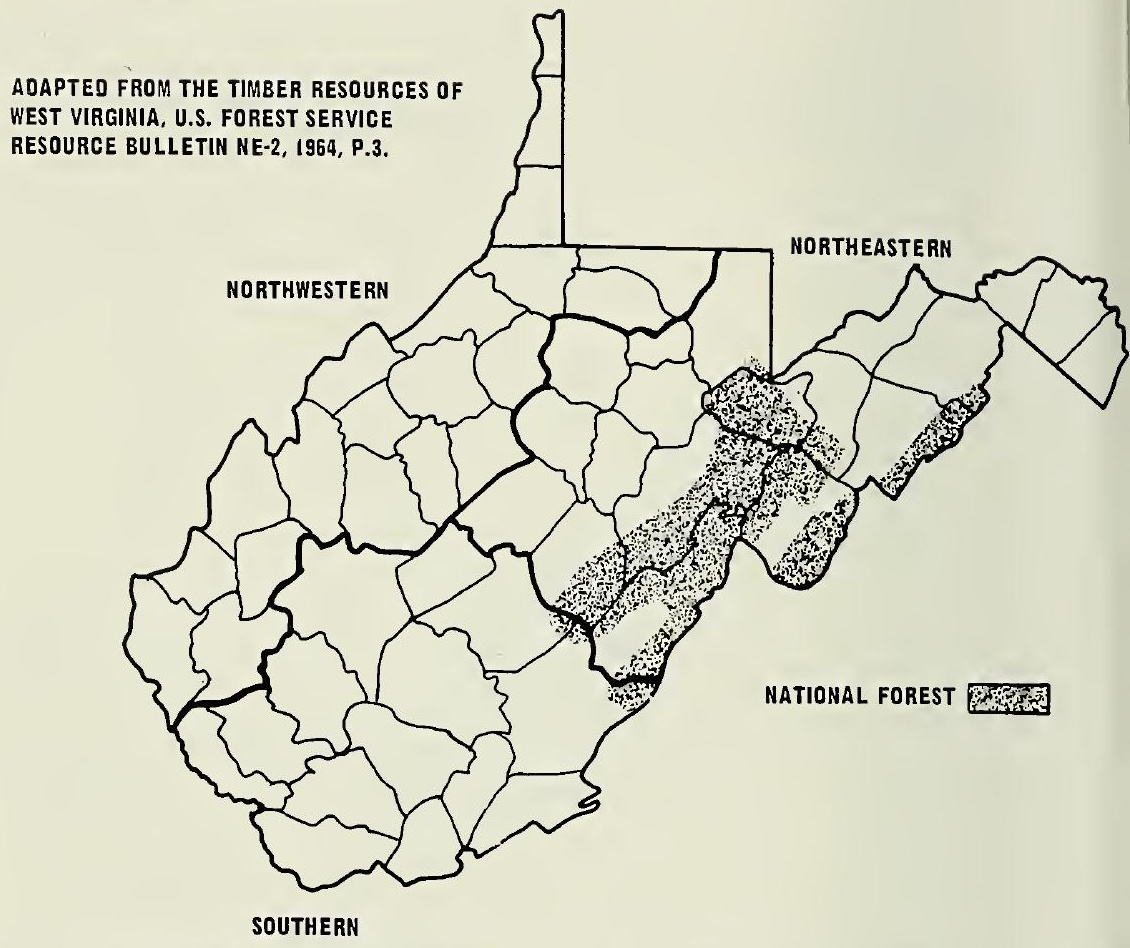

FIGURE 4. U.S. Forest Service Georgraphic Sampling Strata in West Virginia, 1961.

indicated by Thomas and Pasto ${ }^{20}$ the incidence of damage to agricultural crops from wildlife is quite high. Thus, we would expect that wildlife would be more abundant in those areas of the State where a significant portion of the land is still devoted to agricultural production.

Data from the Census of Agriculture and annual kill figures tend to support this view. In Northeastern West Virginia the proportion of land in farms is much higher than anywhere else in the State. Further, a breakdown of the use made of agricultural lands indicates that small grain production is heavily concentrated in the Northeastern part of the State (Table 7). Those Northeastern counties which rank very high in the annual kills of deer, bear, and wild turkey, rank very high also in acres of pasture land. Pendleton, Randolph, Grant, Pocahontas, Preston, Hardy, and Hampshire are included among the top 20 counties in areas devoted to pasture (Table 8 ). The land use data indicate also that sev-

2) D. Woods Thomas and Jerome K. Pasto, Costs and Benefits of the Deer Herd, Agricultural Experiment Station, The Penrisylvania State University, Bulletin 610 (University Park: The Pennsylvania State University, 1956), pp. 18-27. 


\section{TABLE 7}

\section{Leading Counties in the Production of Small Grain in West Virginia, 1959*}

\begin{tabular}{lc}
\hline County & Acres of Small Grain \\
\hline Jefferson & 9,215 \\
Berkeley & 7,173 \\
Preston & 5,652 \\
Monroe & 3,465 \\
Greenbrier & 3,308 \\
Hardy & 3,254 \\
Hampshire & 3,083 \\
Pendleton & 2,644 \\
Mason & 2,508 \\
Grant & 2,227 \\
Morgan & 1,751 \\
Pocahontas & 1,454 \\
Ohio & 1,349 \\
Summers & 1,219 \\
Mineral & 1,154 \\
\hline Total Fifteen Counties & 49,456 \\
Total for State & 58,784 \\
Fifteen Counties as a Per Cent of State Total & 88 \\
\hline
\end{tabular}

*United States Bureau of the Census, United States Census of Agriculture: 1959 Vol. 1. Part 25, Counties, West Virginia (Washington: Government Printing Office, 1961), pp. $160-164$.

eral of these counties have a considerable portion of their land devoted to hay production.

In contrast, the counties of Southern West Virginia have a low percentage of total land in farms, relatively few acres of small grain, relatively few acres of hay and, excepting Monroe County, comparatively few acres of pasture land. In turn, the lack of agricultural crops in combination with extensive forests of sawtimber and poletimber has adversely affected wildlife numbers and hence the quality of hunting lands.

\section{HUNTING QUALITY AND NATURAL SUCCESSION IN NORTHWEST WEST VIRGINIA}

The region of West Virginia which is called Northwest by the United States Forest Service presents an interesting situation. On the basis of forest cover and stand-size class, we would expect the area to be quite productive of wildlife. In 1961 approximately 70 per cent of the area was forested and seedlings and saplings made up 30 per cent of the forest, compared to 22 per cent in the Southern and 20 per cent in the Northeast regions. At the same time, it is in this area where farm abandonment has been quite pronounced over the past 20 years. 
Leading Counties in Pasture Acreage, West Virginia, 1959*

\begin{tabular}{lc}
\hline \hline County & Acreage of Pasture \\
\hline Greenbrier & 149,780 \\
Pendleton & 146,745 \\
Randolph & 122,876 \\
Jackson & 119,280 \\
Harrison & 119,199 \\
Grant & 117,080 \\
Roane & 117,049 \\
Monroe & 116,944 \\
Lewis & 114,784 \\
Pocahontas & 110,914 \\
Braxton & 100,421 \\
Preston & 93,672 \\
Hardy & 90,807 \\
Barbour & 86,175 \\
Mason & 84,406 \\
Ritchie & 82,120 \\
Doddridge & 77,857 \\
Hampshire & 75,367 \\
Upshur & 74,312 \\
Marshall & 70,748 \\
\hline Total Twenty Counties & $2,070,536$ \\
Total for State & $3,222,411$ \\
Twenty Counties as a Per Cent of State Total & 64 \\
\hline
\end{tabular}

*United States Bureau of the Census, United States Census of Agriculture: 1959, Vol. I, Part 25, Counties, West Virginia (Wachington: Government Printing Office, 1961, pp. 112-116.

It is generally held that recently abandoned farm lands which have reverted to seedlings and saplings furnish desirable wildlife habitat, especially for deer. In a 1958 bulletin, DeGarmo and Gill pointed out that this section of West Virginia had the best range potential for deer of any area in the State. ${ }^{21}$ According to their analysis, the food supply was much better in this area, and as a result the deer that were killed were significantly heavier than these killed in the Northeast or Southern regions. ${ }^{22}$

In spite of these seemingly favorable physical characteristics of the habitat, the annual kill figures for deer, bear, and wild turkey suggest that the area has relatively poor quality hunting in comparison with the Northeast region. None of the counties rank among the top 10 counties in annual kill of deer and there are so few bear and wild turkey that legal hunting seasons are generally forbidden by State regulations. In the 1965 regulations there is no legal season for killing bear in the area 
and a very restricted season for killing wild turkey. ${ }^{23}$ Furthermore, small game such as rabbit and quail appear to be relatively scarce in the area.

DeGarmo and Gill attribute the low number of deer in the Northwest region to the lack of protective cover in many areas and an inadequate restocking program. ${ }^{24}$ Regarding small game, it is generally thought that abandoned farm land is favorable to game but this effect may be short-lived. According to Byrd:

There are about 2.5 million acres of abandoned farms in Virginia. During the first few years of abandonment old fields are most favorable for quail and rabbits, but after the fourth year following abandonment game managers should make efforts to hold in check further natural succession of vegetation, for the habitat begins to deteriorate rapidly. 25

Considering the large amount of farm land that was abandoned in the Northwest from 1950 to 1959 , the scarcity of small game in the area appears to be due to habitat destruction through natural succession. Furthermore, since farm abandonment is still occurring in the area and the vegetation is continuing to evolve through the stages of natural succession from seedlings to sawtimber, the habitat will continue to deteriorate, not only for small game but deer as well. Since the area has been characterized for a long time by a large number of small-sized farms that have a relatively poor land resource base, the situation may be manifestation of a statement made in ORRRC 6:

Marginal farms, many of which have abandoned crop and pasture acreage, would at first glance seem to be ideal for the production of farm-type game, and they are better than good farmland under some types of intensive cropping which fails to take into consideration game needs, but in general poor soil not only means poor farms, it also means poor game. ${ }^{26}$

\section{POPULATION CHARACTERISTICS}

Another factor which can and does affect the quality of hunting lands in many states is the number of people. Generally, an increasing population is considered to be detrimental to the quality of hunting lands. Although the statement is generally true, there are three discriminations that should be made of the population variable before its influence on hunting quality can be adequately assessed, namely the number of people, their concentration and the number who hunt. As the

23West Virginic Hunting-Trapping Regulations, 1965-1966, West Virginia Department of Natural Recources (Charleston: West Virginia Department of Natural Resources, 1965), pp. 3-4.

24DeGarmo and Gill, op. cit., pp. 37-46.

25M. A. Byrd, "Relation of Ecological Succession to Farm Game in Cumberland County in the Virginia Piedmont," Journal of Wildife Management, Vol. XX (1965), pp. 188-195.

26 Hunting in the Crnitea states-Its Present rnd Future Role, Outdoor Recreation Resources Review Commistior, Study Report Number 6 (Washington: Government Printing Office, 1962 ), p. 13 . 
population increases in a given area, there is a strong tendency for land use patterns to shift. Land is not only used more intensively but there are shifts in use from agricultural to non-agricultural purposes. Buildings, highways, parks, etc., displace row crops, pasture, hay, and forest land. As these displacements occur, there is quite often an accompanying deterioration in the wildlife habitat. Furthermore, to the extent that an increasing population means a larger number of hunters that will be hunting on the same or a smaller area of land, the habitat will deteriorate due to increased use.

The population of West Virginia is not very large when compared with other states and for the past 15 years has been steadily declining. The Bureau of the Census reported that the population numbered $1,901,974$ in $1940,2,005,552$ in $1950,1,860,421$ in 1960 , and $1,812,000$ on July 1, 1965. ${ }^{{ }^{7} 7}$ Between 1950 and 1965 there was a net loss of 200,000 persons, and the average annual rate of decrease was approximately 0.65 per cent.

The declining population of West Virginia has been accompanied by a declining trend in the sale of hunting licenses. In 1955 approximately 260,000 hunting licenses were sold, but in 1963 only 200,000 were sold (Table 9).

At the time of the 1960 Census, 62 per cent of the State's population resided in areas classified as rural. ${ }^{28}$ Three cities had more than 50,000 but less than 100,000 population, four had between 25,000 and 50,000 population, and eight had between 10,000 and 25,000 population. ${ }^{29}$

In spite of the large proportion of rural residents and the absence of large cities, the population of West Virginia is largely concentrated around the western and northern periphery of the State, in the Kanawha River Valley, and in those counties which make up what is known as the Southern coalfields. Sixteen of the 55 counties in the State account for 62 per cent of the total population. ${ }^{30}$ These counties are, by location, Monongalia, Harrison, Marion, Ohio, Hancock, and Brooke in the Northern section of the State; Wood along the western boundary; Cabell and Kanawha in the Kanawha River Valley; McDowell, Mingo, Logan, Wyoming, Fayette, and Boone in the Southern section of West Virginia.

27United States Bureau of the Census, United States Ccnsus of Population: 1960, Gmeral Population Characteristics, West Virginia, Final Report PC(1)-50B (Washington: Government Printing Office, 1961), p. 26; and, United States Bureau of the Census, Current Population Report, Series P-25, Number 317 (Washington, United States Department of Commerce, 1965).

28 Ibid., p. 25.

29J. Howard Myers, West Virginia Bluebook, Vol. 16 (Charleston: Jarrett Printing Company, 1962), pp. 750-751.

30Mary E. Templeton, Agricul urnl Changes in West Virginia, Agricultural Experiment Station, West Virginia University, Current Report 38 (Morgantown: West Virginia Univer. sity, 1963). Table 51 . 


\section{TABLE 9}

\section{Number of Paid Hunting License Holders in West Virginia, 1955-1963*}

\begin{tabular}{rr}
\hline \hline Year & Number \\
\hline 1955 & 260,000 \\
1956 & 275,000 \\
1957 & 281,000 \\
1958 & 274,000 \\
1959 & 279,000 \\
1960 & 221,000 \\
1961 & 211,000 \\
1962 & 208,000 \\
1963 & 200,000 \\
\hline
\end{tabular}

*United States Bureau of the Census, Statistical Abstracts of the United States: 19561963, Seventy-seventh through Eighty-fourth editions (Washington: Government Printing Office 1956-1963; and, Hunting und Fishing Sales Account Audit, 1962, West Virginia Department of Natural Resources (Charleston: West Virginia Department of Natural Re-sources, 1962).

As noted earlier, the influence of population on the quality of hunting lands is not a primary concern of this study. However, a comparison of the data in Figure 5 with that in Figures 1, 2, and 3 suggests that in areas where population concentrations are greatest, wildlife numbers tend to be relatively low. Of the 20 counties with population densities exceeding 75 persons per square mile not one is included in the 10 ranking counties for annual kill of deer. It is noted also that population densities per square mile are lowest in the eastern section of the State, the area of highest annual kills of deer, wild turkey, and bear.

In light of the declining population, the decrease in sales of hunting licenses, the areas where people are concentrated, and the areas where annual kills of wildlife ate highest, the conclusion seems inescapable that population is not currently a major factor in the hunting situation in West Virginia. Regardless of the detrimental influence that population may have had on the quality of hunting lands in the past, that influence must be diminishing along with the population and the number of hunters.

Summarizing briefly: On the basis of (1) kinds of wildlife that are available for hunting, (2) annual kills of wildlife, (3) forest-open land, (4) stand-size classes of forest, (5) extensiveness of the forest cover, including size of tracts and their location, (6) use of the land for row crops, hay, small grains, and pasture, and (7) population characteristics, the belief that the quality of hunting lands in West Virginia is relatively low is generally supported by secondary information. Further, the relatively poor quality hunting lands in most areas of the State are highly related to habitat deterioration through natural succession. 
As noted earlier, the quantity of land in farms in West Virginia declined precipitously over the period 1945-1960, especially in the central and northwest regions, and once these abandoned farm lands were caught up in the process of natural succession, the quality of the hunting habitat gradually detcriorated. In addition, the habitat in northeast and southern West Virginia continued to deteriorate with the maturing of the forests in those areas. The U. S. Forest Service referred to this dynamic growth in terms of an explosion in the supply of timber. However, in terms of wildlife habitat the increasing supply of sawtimber, with the expanding acreage of forest land, has actually led to a deterioration in the quality of hunting lands; an evolutionary phenomenon which is aptly stated in ORRRG 6:

\begin{abstract}
Succession is a natural process of the shifting composition of vegetation and the replacement on the same terrain of one community by another. This is a process that occurs here and there under pristine conditions because of changes in climate, soil, drainage, erosion, etc. However, man has rapidly produced drastic and widespread alterations in the landscape, destroying natural con. munities by lumbering, agriculture, and grazing. The succession that is currently resulting in habitat deterioration for game that many States referred to is mostly that which occurs naturally where man has ceased his interference, especially on abandoned cropland and pasture and following lumbering and fire ... Browse growing beyond reach of deer as second-growth forests grow older and taller and shade out undergrowth bushes . . high closed forest, especially if homogeneous as in pine woods, is not as productive of game in kinds or quantity as landscape in a variety of cover types and habitats. ${ }^{31}$
\end{abstract}

\title{
QUALITY EVALUATIONS BY LANDOWNERS
}

A more specific assessment of the quality of privately owned hunting lands was made by interviewing a sample of landowners and obtaining from them a quality rating of their land for hunting. Admittedly a more objective assessment of quality of privately owned lands might be obtained by isolating individual tracts of land around the State and on each tract conducting a study of the number and kinds of wildlife, the available food supply, and protective covering. However, for purposes of this study it was assumed that landowners could make an adequate quality discrimination of their lands because:

1. They are familiar with the physical habitat of their land.

2. They travel over their land periodically and can observe the wildlife.

3. They control access to their lands and by virtue of such control are able to note the species and quantity of wildlife killed on their land.

31 Hunting in the Uniled States-Its Present and Future Role, Outdoor Recreation Resources Review Commission, Study Report Number 6 (Washington: Government Printing Office, 1962), pp. 41-42. 


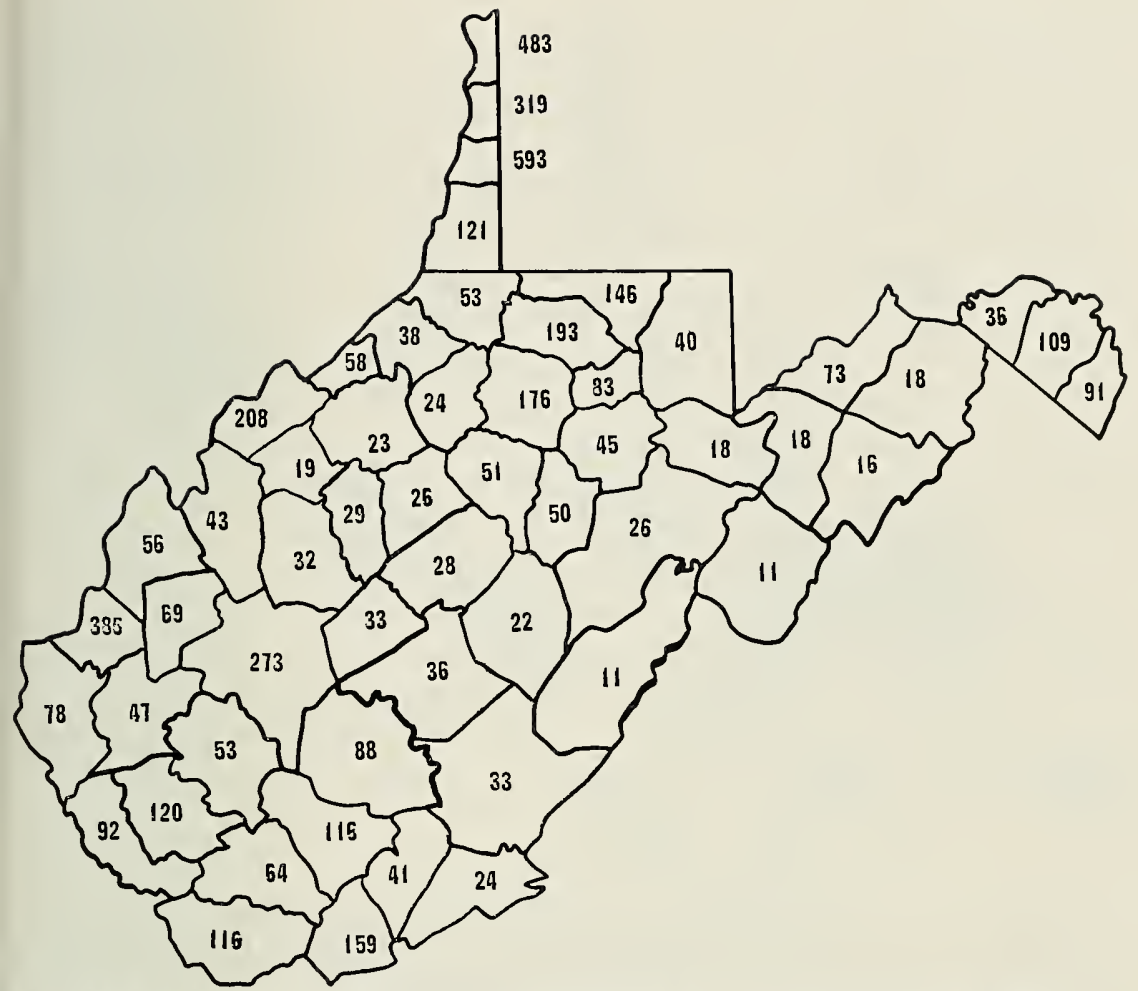

FIGURE 5. Population Densities per Square Mile in West Virginia, 1964.

4. Many landowners hunt on their land, as well as the land of others, and are thus able to evaluate the hunting quality of their land.

Each landowner was asked to make an overail evaluation of his land on the basis of species available, their numbers, available food supply, and protective cover from weather and man. Further, each landowner was asked to rank his land as excellent, good, average, below average, poor, none, or don't know for each of nine kinds of wildlife.

The landowner sample was randomly chosen by use of the following procedure. Initially, the State was stratified into three major regions and two sub-regions (Figure 6). The major regions are labelled Eastern, Southern, and Northwestern. The two sub-regions are metropolitan areas and were excluded from sample consideration due to the considerable influence of population.

After stratifying the State, a ranclom selection of counties was made in each of the major regions. Next, a random sample of landowners was 


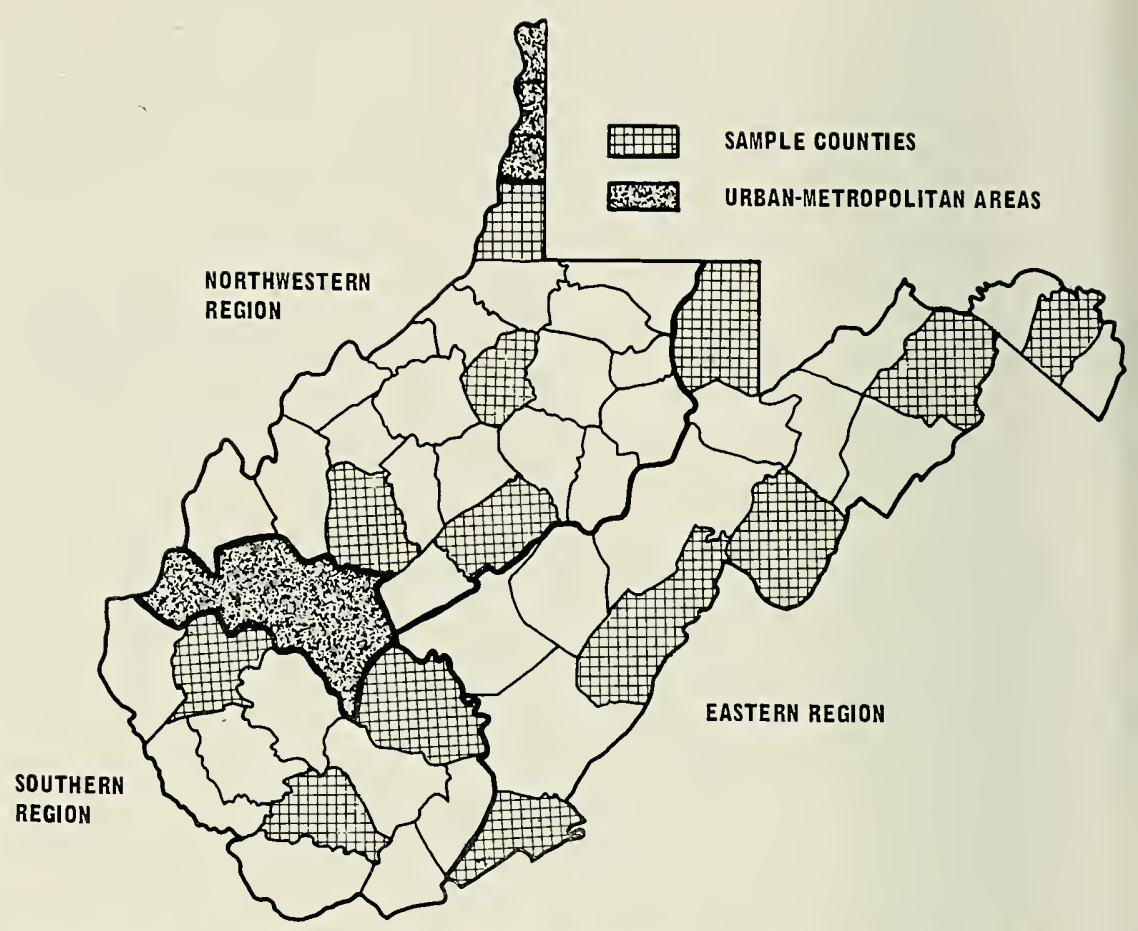

FIGURE 6. Regions and Metropolitan Areas in West Virginia and Sample Counties in Each Major Region, 1965.

obtained by using the land tax records in each of the sample counties. Landowners who were selected by the above procedure were visited during the summer of 1965 , at which time personal interviews were made to solicit information for this study.

Differences in the quality ratings made by landowners were expected but these differences were considered less important within a county than among counties. Further, it was expected that differences in quality ratings would be less important among counties within a region than among counties between regions. From secondary sources of information it was evident that the quality of hunting lands in the Eastern region of the State was superior to that in the Southern or Northwestern regions. ${ }^{32}$ At the same time it was noted that the quality of hunting lands in the Northwestern region was superior to that in the Southern region. On this basis significant differences were expected in quality ratings among regions and among counties in different regions.

32 These regions are not identical with those used by the Forest Service, United States Department of Agriculture for sampling purposes. 
It was assumed that differences among counties in landowner evaluations would be more significant with respect to big game species, i.e., white-tailed deer, bear, and wild turkey, than with small game species such as rabbit, squirrel, and quail. The habitat requirements are simply more stringent for big game than for small game. Farm game such as rabbit, ruffed grouse, and quail need only small areas of brush, thicket, fence rows or "edge" and such areas are found throughout the State. Squirrel, the most sought after game animal in West Virginia, require a forest which contains mast trees such as oaks, beeches, hickories. In addition, den trees are needed for protection and reproduction..$^{33}$ In each of the three major regions, oaks, beeches, and hickories make up more than 70 per cent of the forest. ${ }^{34}$ As a result, squirrel are found throughout the State.

As noted earlier, big game species are highly concentrated in the Eastern regions. Within this region the combination of higher elevations, forest cover, stand-size class, agricultural base, and low population densities all converge to provide the best habitat in the State for big game species. In conclusion, we would expect that differences among counties in landowner evalutions would be less important for small game than for big game.

\section{RESULTS OF LANDOWNER QUALITY EVALUATIONS}

From the standpoint of landowner evaluations, the data in Tables 10 through 18 support the view that the quality of hunting lands depends upon the wildlife under consideration and upon the county and region of the State. For instance, 36 per cent of all landowners in the sample indicated that the quality of their lands for squirrel hunting was above average. On the other hand, less than 10 per cent of the landowners ranked their lands as above average for hunting wild turkey. Comparable figures for groundhog, rabbit, white-tailed deer, ruffed grouse, quail, and bear were, respectively, 69, 32, 27, 17, 15, and 1 .

From an aggregate view the information in Tables 10 through 18 indicates rather clearly the relatively low hunting quality of privately owned lands for ruffed grouse, wild turkey, quail, bear, and to a lesser extent, white-tailed deer. Over three-fourths of the landowners indicated that the hunting quality of their lands for wild turkey and bear was below average. In addition, over 50 per cent of the landowners noted that their lands were below average in quality for hunting ruffed grouse and 


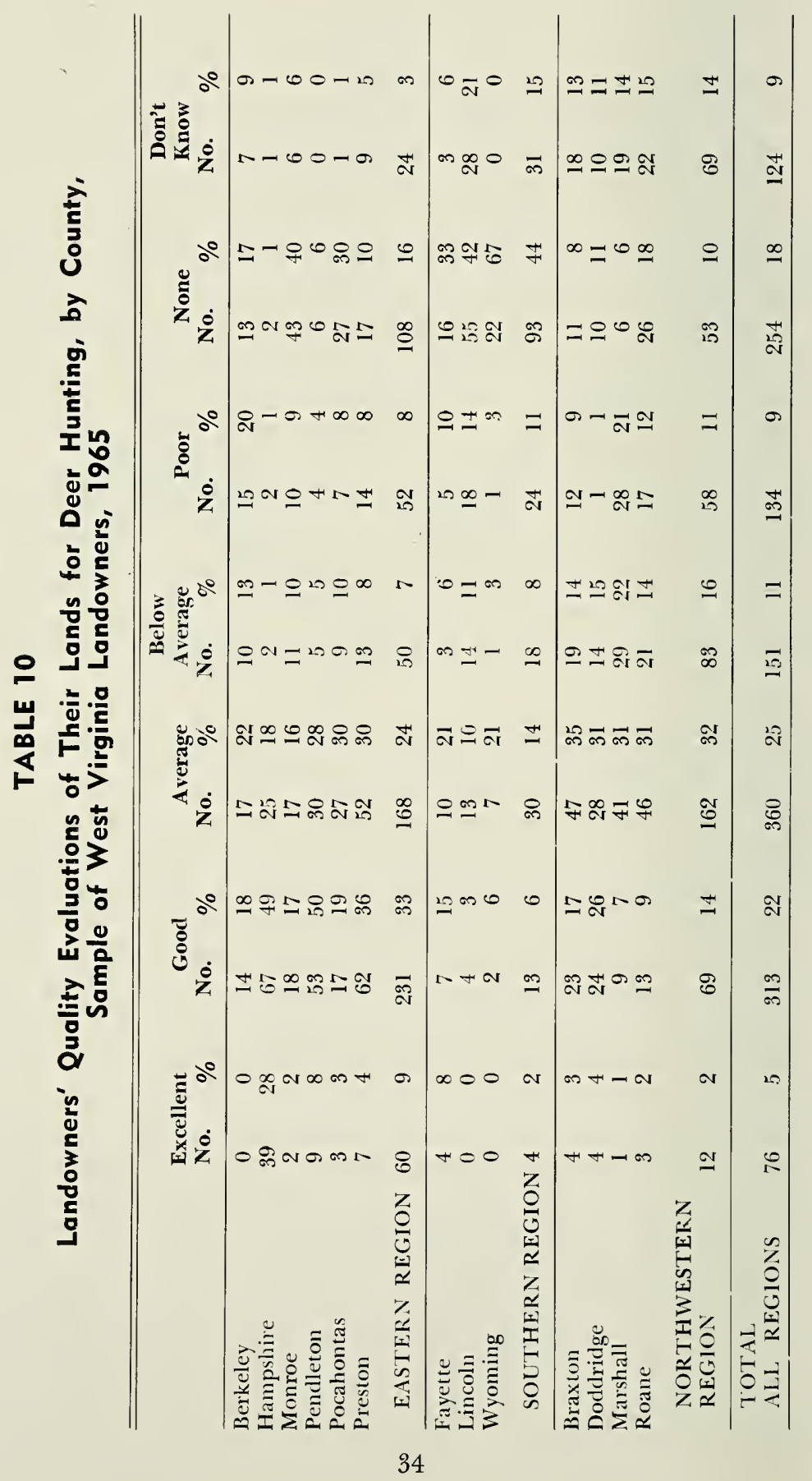




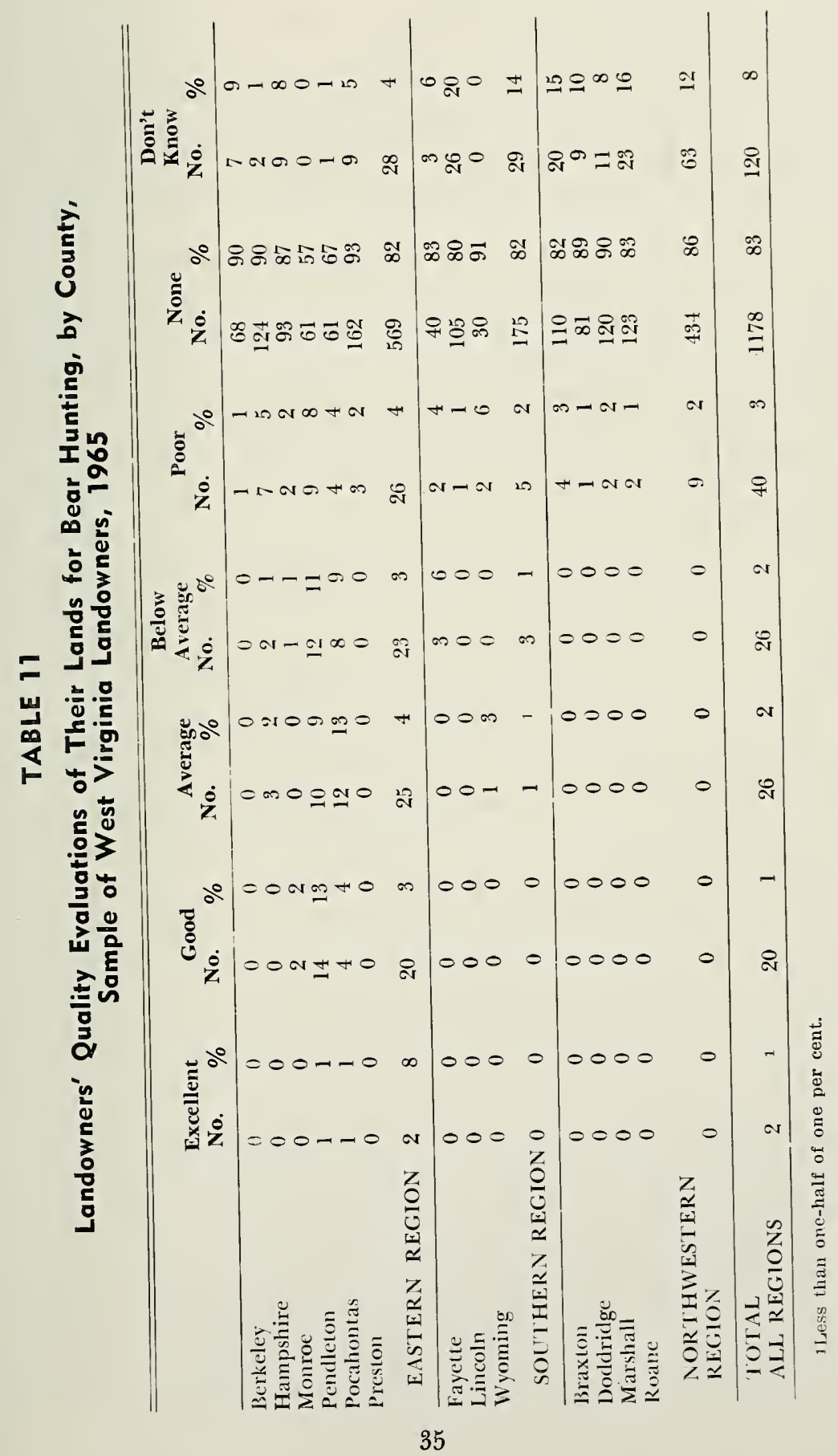


quail. Comparable evaluations for deer, rabbit, and squirrel were, respectively, 38,30 , and 25 .

On the basis of landowner evaluation it can be concluded that, overall, the quality of hunting lands for groundhog, squirrel, and rabbit is relatively good. On the other hand the quality of hunting lands for ruffed grouse, wild turkey, bear, and to a lesser extent, deer, is relatively poor.

In spite of these aggregate conclusions there is considerable variation in the quality of hunting lands among regions and among counties in a given region. For instance, 42 per cent of the landowners in the Eastern region indicated that their lands were above average for hunting deer. In comparison, only 8 per cent of the landowners in the Southern region and 16 per cent of the owners in the Northwestern region rated their lands as above average for deer hunting. Among the counties in the Eastern region, the proportion of landowners ranking their lands as above average for deer hunting ranged from a low of 18 per cent in Berkeley County to a high of 77 per cent in Hampshire County. In the Northwestern region the above average evaluations for deer hunting ranged from a low of 8 per cent in Marshall County to a high of 30 per cent in Doddridge County. Similarly, the range in the Southern region was from 3 per cent in Lincoln County to 23 per cent in Fayette County.

Overall, 72 per cent of all landowners indicated that there were no wild turkey on their lands. However, almost all of the landowners who ranked their lands for wild turkey were located in the Eastern region. Approximately 13 per cent of the landowners in this region ranked their lands as above average for hunting wild turkey. In comparison, only 1 per cent of the landowners in the Southern and Northwestern regions ranked their lands as above average. Among the counties in the Eastern region the proportion of owners ranking their lands as above average ranged from a high of 44 in Pendleton County to a low of zero in Preston County. Considering the small number of landowners who ranked their lands as above average for wild turkey in the Southern and Northwestern regions, the ranges among the counties in these regions are omitted. Actually these landowners' assessments point out rather clearly that among the counties sampled, Pendleton, Hampshire, and Pocahontas are the only ones with a significant number of bear and wild turkey.

In addition to deer and wild turkey, the Eastern region had higher quality ratings for ruffed grouse, quail, rabbit, groundhog, and bear than either the Southern and Northwestern regions. The highest quality ratings for squirrel and raccoon were made by landowners in the Northwestern region. Again these regional differences, large as they are, are 


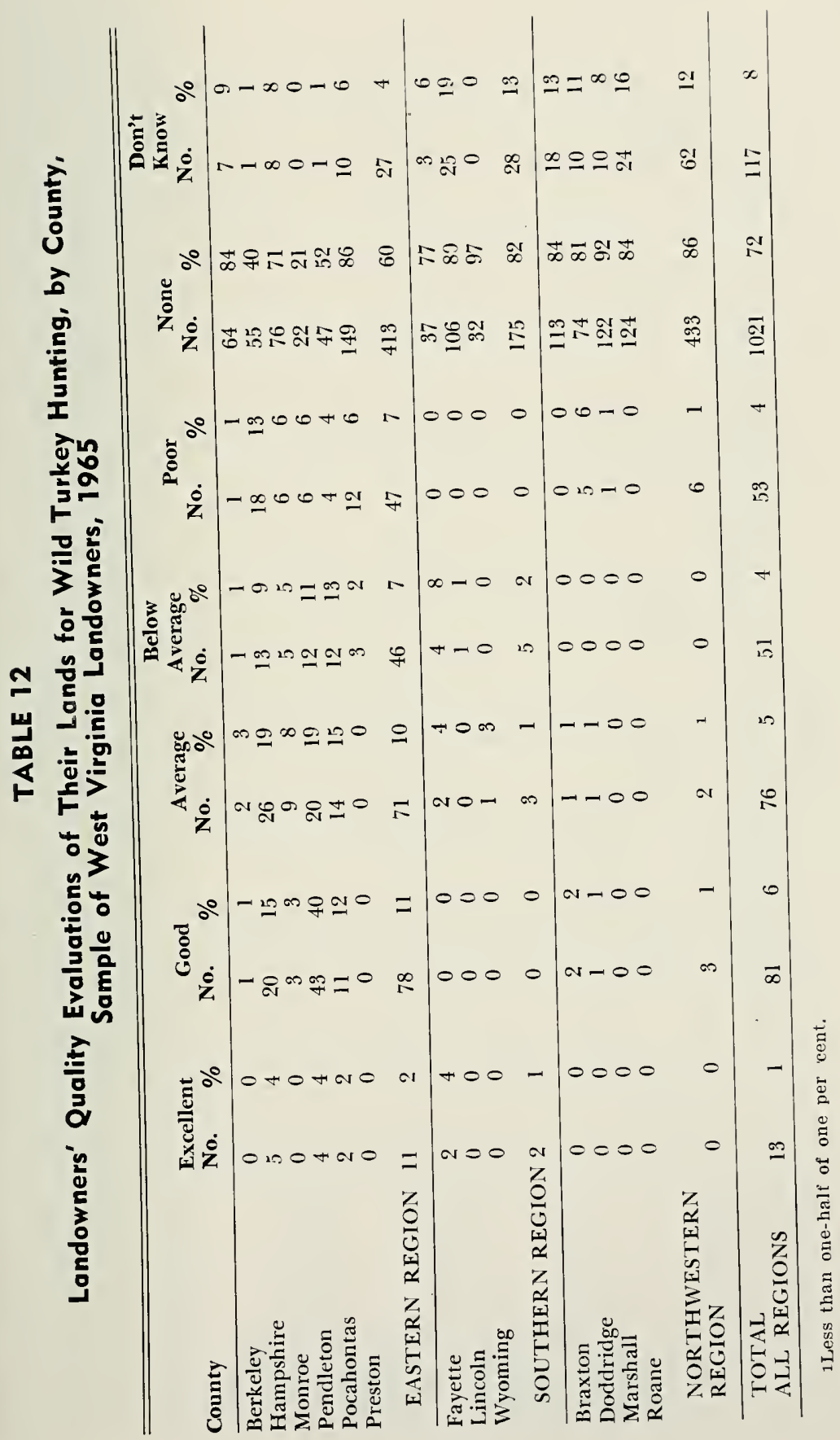




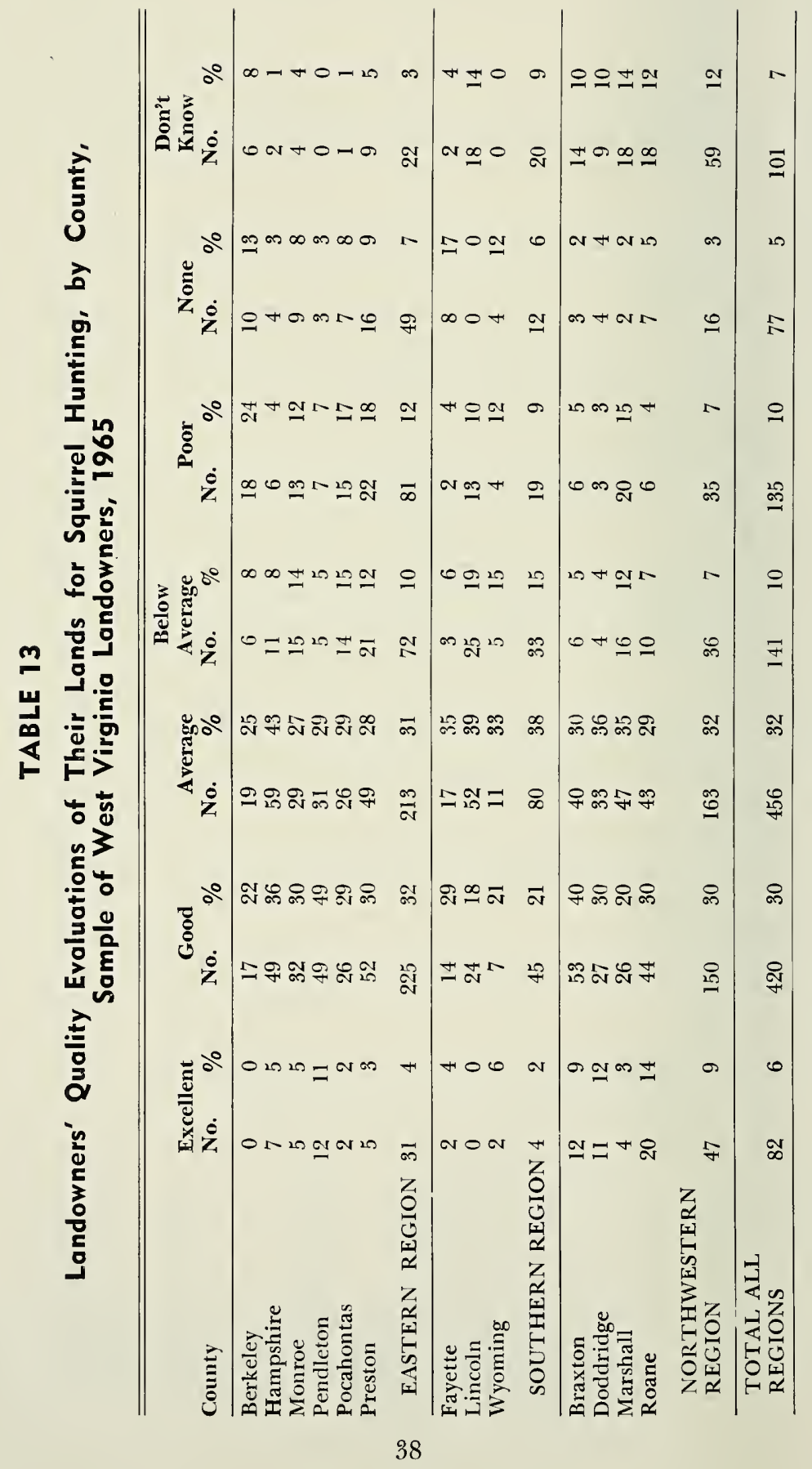




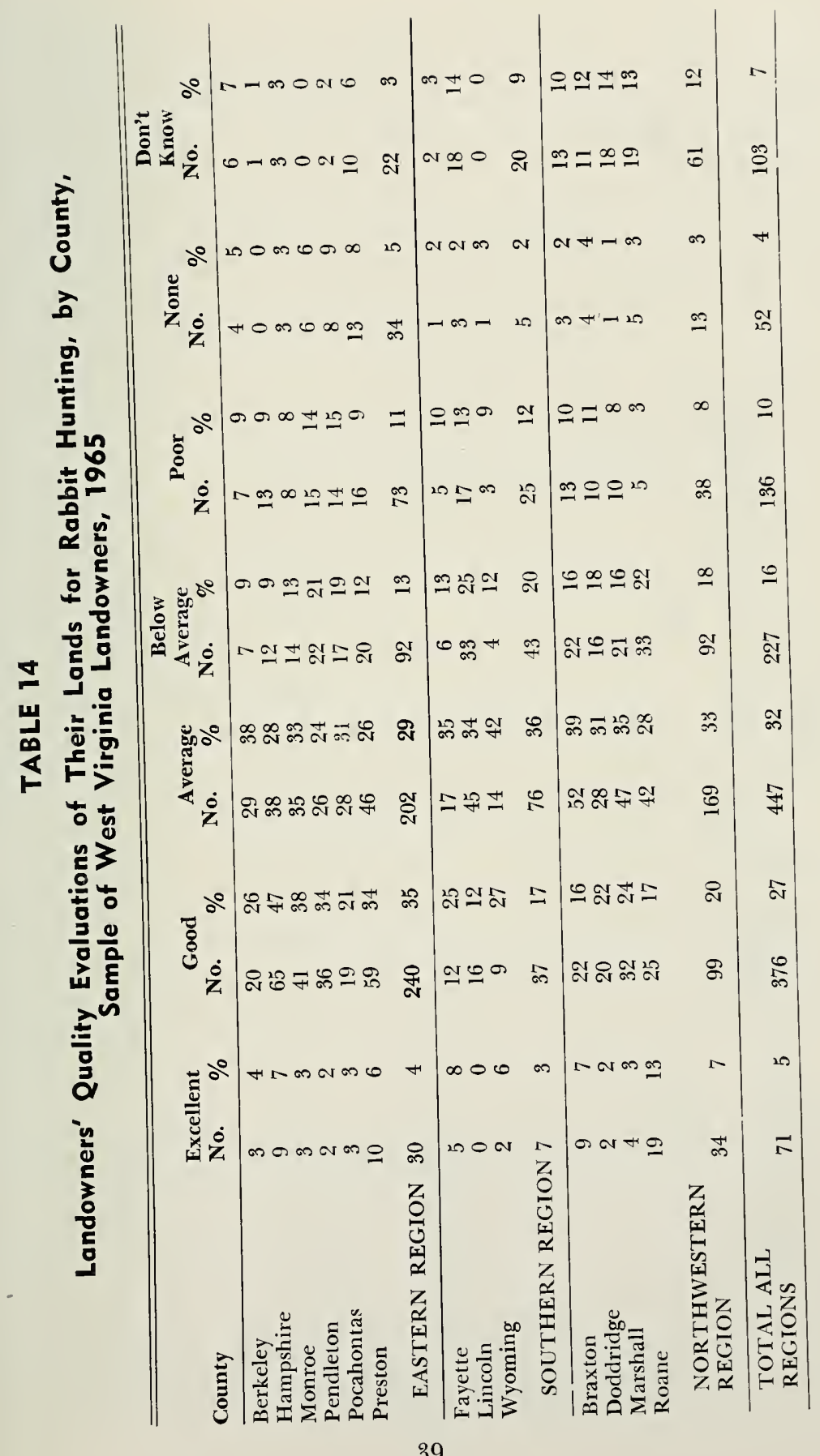




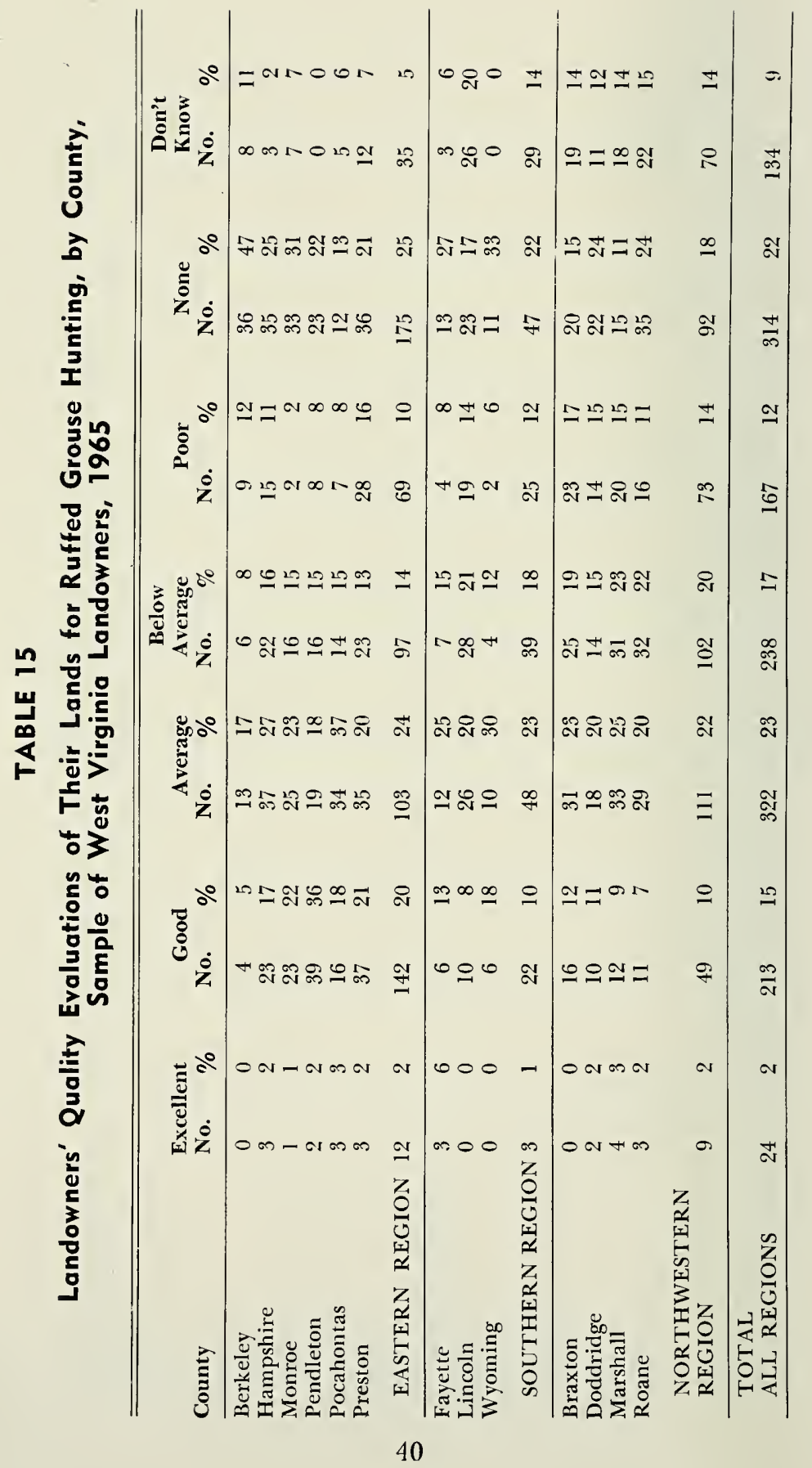


not as great as the differences among counties within a region, or among counties between regions (Table 19) .

In general, these landowner evaluations support the conclusions drawn from aggregate quality considerations. The Eastern region has relatively higher quality hunting lands than either the Southern or Northwestern region. It appears that this more favorable situation is due to a combination of factors such as relatively low human population densities, larger proportion of land in agricultural uses, relatively smaller landholdings, and a more favorable physical environment in the form of vegetation for food and cover.

For small game species such as rabbit, quail, ruffect grouse, and squirrel the differences in quality ratings among regions and among counties within a region were not as great as the variations in quality ratings for big game species. For example, the range in above average quality evaluations for cleer hunting among regions was from 8 per cent in the Southern region to 42 per cent in the Eastern region (Table 19). Among counties in each region the evaluations for deer ranged from 18 to 77 per cent in the Eastern region, 3 to 30 per cent in the Northwestern region and 3 to 23 per cent in the Southern region. On the other hand the range in above average quality ratings for squirrel among regions was 23 per cent in the Southern region to 39 per cent in the Northwestern region. Among the counties in each region the proportions ranged from 23 to 49 per cent in the Northwestern region, 22 to 57 per cent in the Eastern region and 18 to 33 per cent in the Southern region.

In a similar fashion, 39 per cent of the landowners in the Eastern region, 27 per cent in the Northwestern region, and 20 per cent in the Southern region ranked their lands as above average for rabbit hunting. Within the Eastern region these landowner evaluations among counties ranged from 24 to 54 per cent. In the Northwestern region the range was from 23 to 30 per cent, and in the Southern region the range was from 12 to 33 per cent.

\section{STATISTICAL TEST OF QUALITY EVALUATIONS}

How significant are these variations in quality ratings among counties and among regions? Are they real differences in quality, or simply insignificant errors that would be noted with any randomly drawn sample? To test their statistical significance an analysis of variance test was made for each of the nine species of wildlife for which quality evaluations were made by the random sample of landowners. Two separate tests were employed for each species. One test was made to check the significance of the variations among counties and the other to check 


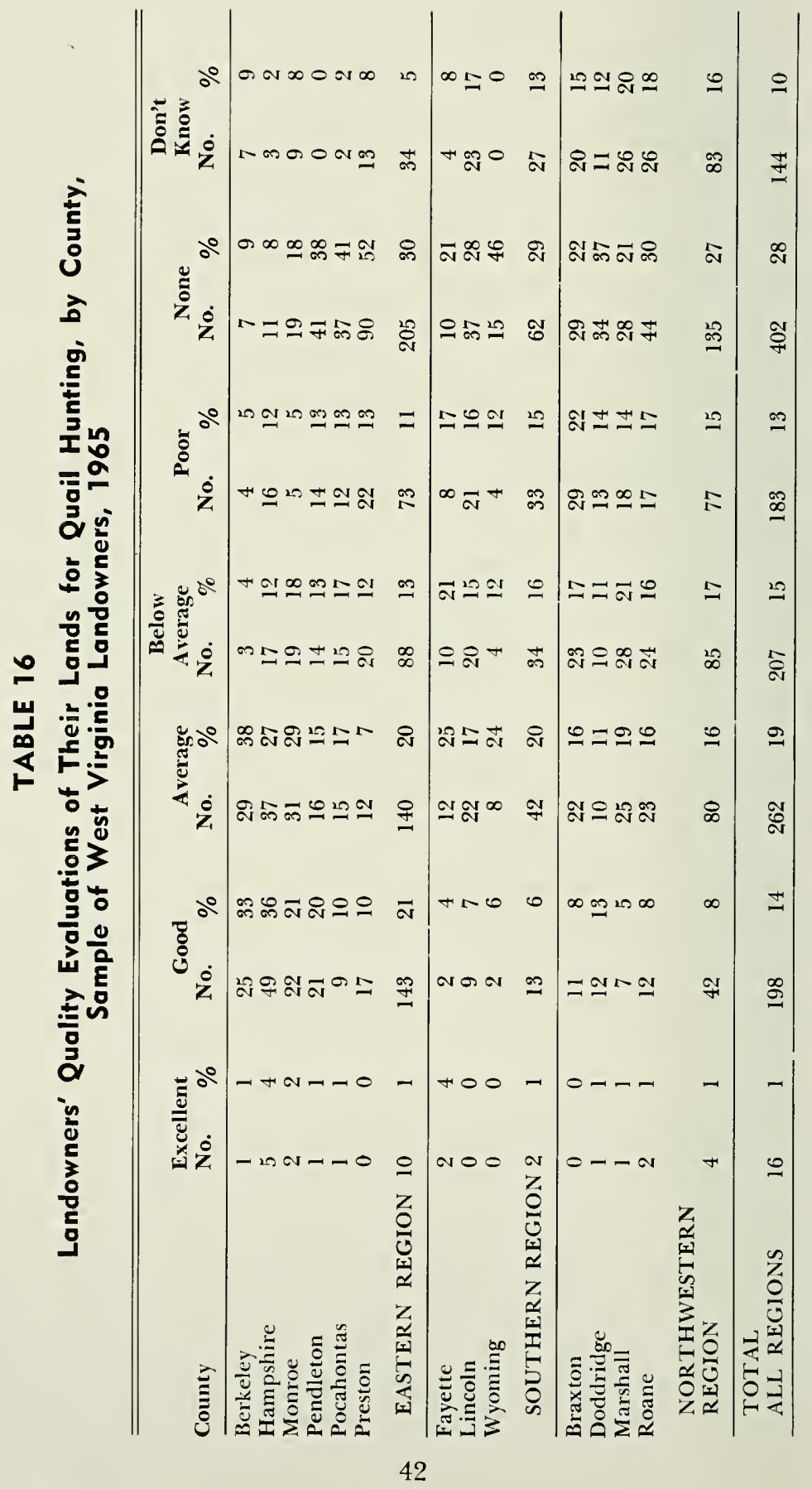




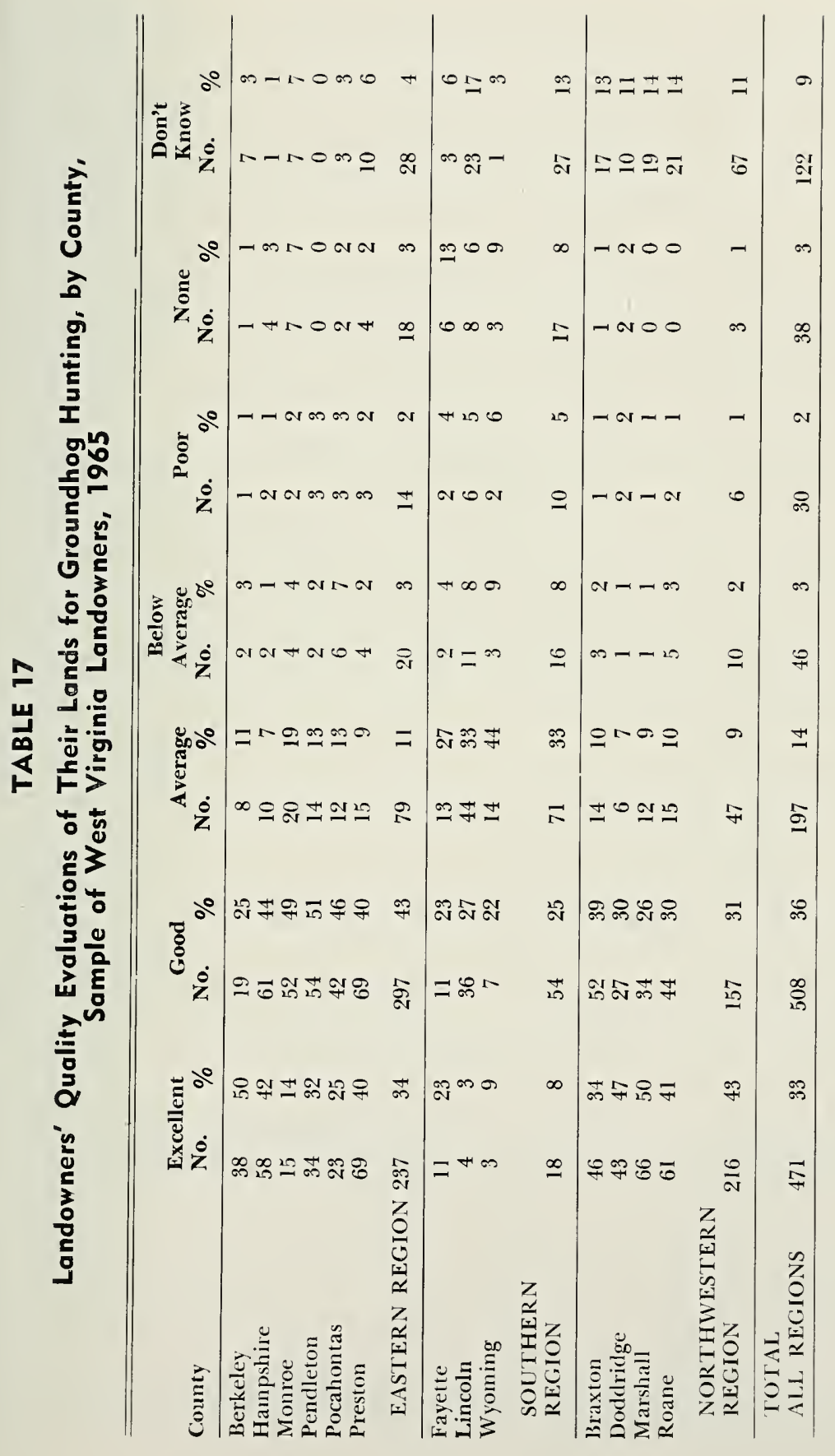


the significance of the variations among regions. For the among-counties test the null hypothesis was: there is no difference in the quality ratings among regions.

As shown in the Appendix, the analysis of variance tests indicate that the variations in quality ratings among counties and among regions are real differences and not simply random chance that occurs when samples are drawn from a population. For each of the nine species of wildlife, and at both the 95 and 99 percentile levels the variations are of such magnitude that the calculated $F$ values exceed the theoretical $F$ values. Under these circumstances the null hypothesis of no difference among. counties or among regions is rejected. Only once in a hundred times would variations as large as these be expected on the basis of chance alone.

\section{FARM AND NON-FARM QUALITY EVALUATIONS}

It is generally known that lands which are being intensively used for growing of row crops provide a relatively poor wildlife habitat when compared with lands that are being more extensively used for such agricultural enterprises as livestock, hay, and pasture. Further, it is generally believed that lands which are being extensively used in agricultural production, such as we find in most of West Virginia, provide a better habitat for many wildlife species than non-farm lands. Species such as rabbit, quail, ruffed grouse, and deer obtain a source of food as well as protective cover along the borders between cropland and woodland, along fence rows, in hay fields and pasture land.

In light of these considerations, if there is really a significant quality difference in the habitat between farm and non-farm lands, it should be reflected in the quality evaluations made by landowners. ${ }^{35}$ It was expected that within a given county the wildlife habitat on lands presently being farmed would be superior to the habitat on lands that were not being farmed, and that this difference would manifest itself in relatively higher quality ratings on lands presently being farmed.

\section{STATISTICAL TEST OF DIFFERENCES BETWEEN FARM AND NON-FARM QUALITY RATINGS}

A discriminatory test (chi-square) was made of landowner evaluations under the null hypothesis of no difference between farm and nonfarm evaluations within a county. Contrary to widespread beliefs, these chi-square tests, by species, indicate very little difference in the

35 Farm evaluations are those made by landowners who own land that is currently being farmed. Non-farm evaluations are those made by landowners who own land that is not
currently being farmed. 


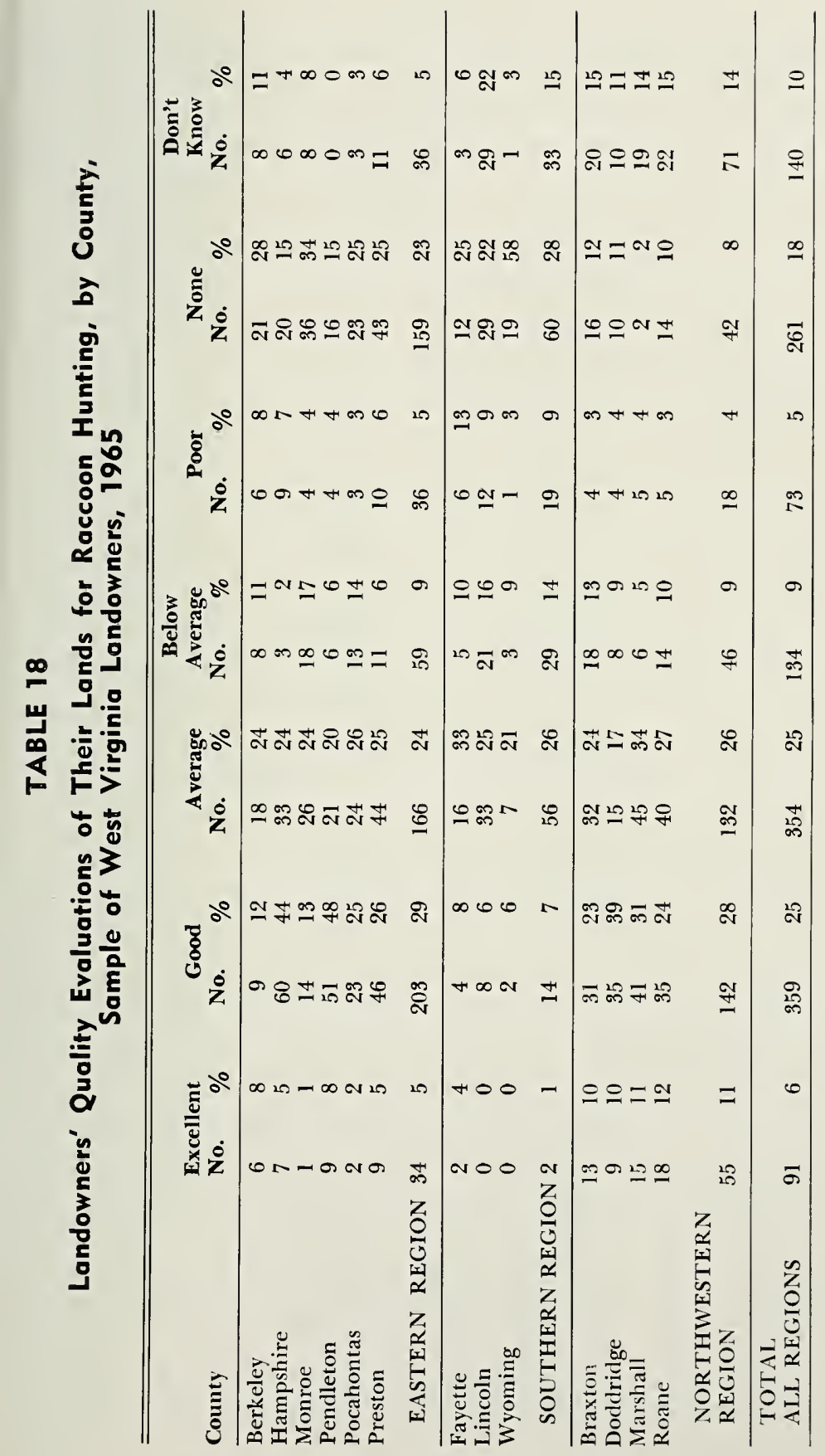




\section{TABLE 19}

\section{Proportion of Landowners Who Evaluate Their Lands as Above Average Quality for Hunting, by Kind of Wildlife, Sample of West Virginia Landowners, 1965}

\begin{tabular}{|c|c|c|c|}
\hline $\begin{array}{l}\text { Type of } \\
\text { Wildlife }\end{array}$ & Region & $\begin{array}{c}\text { Proportion of } \\
\text { Landowners }\end{array}$ & $\begin{array}{l}\text { Range Among Counties } \\
\text { in the Region }\end{array}$ \\
\hline Deer & $\begin{array}{l}\text { Eastern } \\
\text { Northwestern } \\
\text { Southern }\end{array}$ & $\begin{array}{r}42 \\
\text { I6 } \\
8\end{array}$ & $\begin{array}{r}18-77 \\
8-30 \\
3-23\end{array}$ \\
\hline Bear & $\begin{array}{l}\text { Eastern } \\
\text { Northwestern } \\
\text { Southern }\end{array}$ & $\begin{array}{l}3 \\
0 \\
0\end{array}$ & $\begin{array}{l}0-14 \\
0 \\
0\end{array}$ \\
\hline Wild Turkey & $\begin{array}{l}\text { Eastern } \\
\text { Northwestern } \\
\text { Southern }\end{array}$ & $\begin{array}{r}13 \\
1 \\
1\end{array}$ & $\begin{array}{l}0-44 \\
0-2 \\
0-4\end{array}$ \\
\hline Squirrel & $\begin{array}{l}\text { Eastern } \\
\text { Northwestern } \\
\text { Southern }\end{array}$ & $\begin{array}{l}36 \\
39 \\
23\end{array}$ & $\begin{array}{l}22-57 \\
23-49 \\
18-33\end{array}$ \\
\hline Rabbit & $\begin{array}{l}\text { Eastern } \\
\text { Northwestern } \\
\text { Southern }\end{array}$ & $\begin{array}{l}39 \\
27 \\
20\end{array}$ & $\begin{array}{l}24-54 \\
23-30 \\
12-33\end{array}$ \\
\hline $\begin{array}{l}\text { Ruffed } \\
\text { Grouse }\end{array}$ & $\begin{array}{l}\text { Eastern } \\
\text { Northwestern } \\
\text { Southern }\end{array}$ & $\begin{array}{l}22 \\
12 \\
11\end{array}$ & $\begin{array}{l}5-38 \\
9-13 \\
8-19\end{array}$ \\
\hline Quail & $\begin{array}{l}\text { Eastern } \\
\text { Northwestern } \\
\text { Southern }\end{array}$ & $\begin{array}{r}22 \\
9 \\
7\end{array}$ & $\begin{array}{c}10-40 \\
6-14 \\
6-8\end{array}$ \\
\hline Groundhog & $\begin{array}{l}\text { Eastern } \\
\text { Northwestern } \\
\text { Southern }\end{array}$ & $\begin{array}{l}77 \\
74 \\
35\end{array}$ & $\begin{array}{l}63-86 \\
71-77 \\
30-46\end{array}$ \\
\hline Raccoon & $\begin{array}{l}\text { Eastern } \\
\text { Northwestern } \\
\text { Southern }\end{array}$ & $\begin{array}{r}34 \\
39 \\
8\end{array}$ & $\begin{array}{r}14-56 \\
33-49 \\
6-12 \\
\end{array}$ \\
\hline
\end{tabular}

evaluations of hunting quality on farm and non-farm lands (Appendix). Out of 117 individual chi-square tests, the null hypothesis of no difference between farm and non-farm was rejected in only 11 cases. Further, these rejections were distributed as follows:

Squirrel

Ruffed Grouse

Rabbit

Raccoon

Groundhog

Quail
- Null hypothesis rejected in Braxton and Marshall counties.

- Null hypothesis rejected in Doddridge and Preston counties.

- Null hypothesis rejected in Berkeley County.

- Null hypothesis rejected in Marshall County.

- Null hypothesis rejected in Marshall, Pendleton, Preston, and Lincoln counties.

- Null hypothesis rejected in Berkeley County. 
For big game wildlife, deer, bear, and wild turkey, the null hypothesis was accepted in all 13 sample counties for all three species.

What explanttion can be offered for this significant deviation from prevailing opinions? Two factors which play a part in this erosion of generally held beliefs is the overall low quality of hunting in many counties and the stage of natural succession on abandoned farm lands.

As noted in Table 11, approximately 83 per cent of all landowners interviewed stated that there are no bear on their lands. Comparable percentage figures are: wild turkey 72; quail, 28; ruffed grouse, 22; deer, 18; raccoon, 18; squirrel, 5; rabbit 4; and groundhog, 3 . In addition to those who indicated an absence of certain wildlife on their lands, another group of landowners rank their lands as below average or poor for hunting the same species. If these two groups are combined, it is noted that 88 per cent of all landowners either have no bear, or rank their lands very low in hunting quality. Comparable percentage figures are: wild turkey, 80; quail, 56; grouse, 51; deer, 38; raccoon, 32; rabbit, 30; squirrel, 25; and groundhog, 8. Furthermore, for each of the nine species a group of landowners, from 7 to 10 per cent of the total sample, had no idea of the hunting quality of their lands. In conclusion, it is apparent that for bear and wild turkey the hunting quality on most privately owned lands is very low, whether the land is being farmed or not farmed. And, to a lesser extent, both farm and non-farm lands provide low quality hunting for quail and ruffed grouse.

Under prevailing farm operations in West Virginia there is not a great difference in the wildlife habitat on land that has been recently abandoned for farming purposes and on land that is still being farmed. In 1959 approximately half of our commercial farms were classified as livestock farms (other than poultry and dairy farms) and the land on these farms is used extensively in the production of hay, pasture, and livestock. ${ }^{36}$ The final product of these operations is a feeder calf between 350 and 500 pounds which is sold to feeders in Indiana, Ohio, Pennsylvania, and other midwestern states. Under present management practices, the pastures on many of these farms are not much different from the cleserted pasture lands on land which is classified as non-farm land. The presence of cattle is often the feature which differentiates between farm pasture and abandoned farm land in Northwest West Virginia. Inadequate liming, fertilizing, and failure to remove undesirable plant species has led to a large quantity of inferior pastures. There were approximate-

36United States Bureau of the Census. Lnitfd States Census of Agriculture: 1959, Vol. I, Counties, Part 25, West Virginia (Washington: Government Printing Office, 1961), pp. $58-59$. 
TABLE 20

Roughage Consuming Animal Units and Pasture Land,
West Virginia, for Census Years 1925-1959*

\begin{tabular}{|c|c|c|c|c|c|}
\hline \multirow[b]{2}{*}{ Year } & \multirow[b]{2}{*}{$\begin{array}{l}\text { Animal } \\
\text { Units }\end{array}$} & \multicolumn{2}{|c|}{ Total Pasture } & \multicolumn{2}{|c|}{ Open Pasture - Only } \\
\hline & & $\begin{array}{r}\text { Acres } \\
(000 \text { 's })\end{array}$ & $\begin{array}{c}\text { Acres } \\
\text { Per Unit } \\
\end{array}$ & $\begin{array}{c}\text { Total Acres } \\
\text { (000's) }\end{array}$ & $\begin{array}{c}\text { Acres } \\
\text { Per Unit }\end{array}$ \\
\hline 1925 & 696 & 4288 & 6.2 & 3383 & 4.8 \\
\hline 1929 & 710 & 4511 & 6.3 & 3340 & 4.8 \\
\hline 1934 & 794 & 4953 & 6.2 & 3522 & 4.4 \\
\hline 1939 & 725 & & & 3540 & 5.0 \\
\hline 1944 & 714 & 4655 & 6.5 & 3555 & 5.0 \\
\hline 1949 & 664 & 4319 & 6.5 & 3133 & 4.7 \\
\hline 1954 & 680 & 4064 & 6.0 & 2789 & 4.1 \\
\hline 1959 & 604 & 3481 & 5.8 & 2206 & 3.7 \\
\hline
\end{tabular}

*Table supplied by Dr. O. C. Stine, consultant to Department of Agricultural Economics, West Virginia University, Morgantown, West Virginia.

ly six acres of pasture for each animal unit in the State in 1959 (Table 20 ), according to a computation by Stine. ${ }^{37}$

As noted earlier there has been considerable abandonment of farms in West Virginia since 1950. On many tracts of land which have been abandoned for farming purposes, the present owner is a former farmer who has retired from active farming or who has obtained non-farm employment in nearby towns or out of State. Although these lands are not presently being used for agricultural production, the evolutionary process of natural succession has not yet advanced to the state where forests of poletimber and sawtimber predominate. As expressed by many landowners, the land is simply "growing up" or it's "brushland." During this stage of the natural succession cycle the physical habitat is relatively good for deer and, to a lesser extent, for rabbit, groundhog, raccoon, ruffed grouse, and quail.

Briefly, the lack of significant differences between the quality evaluations made by owners of land which is being farmed and owners of land that is not being farmed appears to be related to the almost statewide phenomenon of low quality hunting for certain species, namely, bear, wild turkey, quail, and ruffed grouse. At the same time the recently abandoned farm lands provide a habitat, especially for deer, that is not much different from that found on many West Virginia farms.

37Table supplied in a memorandum from Dr. O. C. Stine, Consulting Agricultural Economist, Department of Agricultural Economics, West Virginia University, Mrorgantown, West Virginia. 
Appendix 
TABLE 21

\section{Results of Analysis of Variance Test of Wildlife Quality Ratings Among Regions in West Virginia, 1965}

\begin{tabular}{|c|c|c|c|c|c|}
\hline $\begin{array}{l}\text { Kind of } \\
\text { Wildlife }\end{array}$ & $\begin{array}{l}\text { Source of } \\
\text { Variation } \\
\end{array}$ & $\begin{array}{l}\text { Degrees } \\
\text { of } \\
\text { Freedom }\end{array}$ & $\begin{array}{l}\text { Sumn } \\
\text { of } \\
\text { Squares }\end{array}$ & $\begin{array}{l}\text { Mean } \\
\text { Square }\end{array}$ & $\begin{array}{l}\text { Calculated } \\
\text { F Value } \\
\end{array}$ \\
\hline Squirrel & $\begin{array}{l}\text { 'Total } \\
\text { Among regions } \\
\text { Within regions }\end{array}$ & $\begin{array}{r}20 \\
2 \\
18\end{array}$ & $\begin{array}{r}2,956,931 \\
2,058,409 \\
898,522\end{array}$ & $\begin{array}{r}1,029,204 \\
49,917\end{array}$ & $20.62 *$ \\
\hline Deer & $\begin{array}{l}\text { Total } \\
\text { Among regions } \\
\text { Within regions }\end{array}$ & $\begin{array}{r}20 \\
2 \\
18\end{array}$ & $\begin{array}{r}2,352,377 \\
988,060 \\
1,364,316\end{array}$ & $\begin{array}{r}494,030 \\
29,996\end{array}$ & $6.52 *$ \\
\hline $\begin{array}{l}\text { Ruffed } \\
\text { Grouse }\end{array}$ & $\begin{array}{l}\text { Total } \\
\text { Among regions } \\
\text { Within regions }\end{array}$ & $\begin{array}{r}20 \\
2 \\
18\end{array}$ & $\begin{array}{r}1,157,996 \\
618,063 \\
539,932\end{array}$ & $\begin{array}{r}309,001 \\
29,996\end{array}$ & $10.30 *$ \\
\hline Rabbit & $\begin{array}{l}\text { Total } \\
\text { Among regions } \\
\text { Within regions }\end{array}$ & $\begin{array}{r}20 \\
2 \\
18\end{array}$ & $\begin{array}{l}2,815,688 \\
1,762,654 \\
1,053,034\end{array}$ & $\begin{array}{r}881,327 \\
58,501\end{array}$ & $15.06^{*}$ \\
\hline Quail & $\begin{array}{l}\text { Total } \\
\text { Among regions } \\
\text { Within regions }\end{array}$ & $\begin{array}{r}20 \\
2 \\
18\end{array}$ & $\begin{array}{l}980,200 \\
438,316 \\
541,963\end{array}$ & $\begin{array}{r}219,158 \\
30,109\end{array}$ & $7.28 *$ \\
\hline $\begin{array}{l}\text { WVild } \\
\text { Turkey }\end{array}$ & $\begin{array}{l}\text { Total } \\
\text { Among regions } \\
\text { Within regions }\end{array}$ & $\begin{array}{r}20 \\
2 \\
18\end{array}$ & $\begin{array}{r}1,390,018 \\
970,054 \\
419,964\end{array}$ & $\begin{array}{r}485,027 \\
23,331\end{array}$ & $20.79 *$ \\
\hline Bear & $\begin{array}{l}\text { Total } \\
\text { Among regions } \\
\text { Within regions }\end{array}$ & $\begin{array}{r}20 \\
2 \\
18\end{array}$ & $\begin{array}{r}1,804,106 \\
1,455,601 \\
348,504\end{array}$ & $\begin{array}{r}727,800 \\
19,361\end{array}$ & $37.59^{*}$ \\
\hline Raccoon & $\begin{array}{l}\text { Total } \\
\text { Among regions } \\
\text { Within regions }\end{array}$ & $\begin{array}{r}20 \\
2 \\
18\end{array}$ & $\begin{array}{r}2,173,554 \\
1,233,504 \\
940,050\end{array}$ & $\begin{array}{r}616,752 \\
52,225\end{array}$ & $11.81^{*}$ \\
\hline Groundhog & $\begin{array}{l}\text { Total } \\
\text { Among regions } \\
\text { Within regions } \\
\end{array}$ & $\begin{array}{r}20 \\
2 \\
18\end{array}$ & $\begin{array}{l}6,684,385 \\
4,165,822 \\
2,518,562\end{array}$ & $\begin{array}{r}2,082,911 \\
139,920\end{array}$ & $14.89^{*}$ \\
\hline
\end{tabular}

*Significantly different at the 95 and 99 percentile levels than the theoretical $F$ values of $\mathrm{F}_{95}=3.55$ and $\mathrm{F}_{99}=6.01$. 
TABLE 22

\section{Results of Analysis of Variance Test of Wildlife Quality Ratings Among Counties in West Virginia}

\begin{tabular}{|c|c|c|c|c|c|}
\hline $\begin{array}{l}\text { Kind Of } \\
\text { Wildlife }\end{array}$ & $\begin{array}{l}\text { Source of } \\
\text { Variation }\end{array}$ & $\begin{array}{l}\text { Degrees } \\
\text { of } \\
\text { Freedom }\end{array}$ & $\begin{array}{c}\text { Sum } \\
\text { of } \\
\text { Squares }\end{array}$ & $\begin{array}{l}\text { Mean } \\
\text { Square }\end{array}$ & $\begin{array}{l}\text { Calculated } \\
\text { F Value }\end{array}$ \\
\hline Squirrel & $\begin{array}{l}\text { Total } \\
\text { Among counties } \\
\text { Within counties }\end{array}$ & $\begin{array}{l}90 \\
12 \\
78\end{array}$ & $\begin{array}{l}680,254 \\
475,017 \\
205,237\end{array}$ & $\begin{array}{r}39,584 \\
2,631\end{array}$ & $15.04^{*}$ \\
\hline Deer & $\begin{array}{l}\text { Total } \\
\text { Among counties } \\
\text { Within counties }\end{array}$ & $\begin{array}{l}90 \\
12 \\
78\end{array}$ & $\begin{array}{l}599,631 \\
228,013 \\
371,617\end{array}$ & $\begin{array}{r}19,001 \\
4,764\end{array}$ & $3.99 *$ \\
\hline $\begin{array}{l}\text { Ruffed } \\
\text { Grouse }\end{array}$ & $\begin{array}{l}\text { Total } \\
\text { Among counties } \\
\text { Within counties }\end{array}$ & $\begin{array}{l}90 \\
12 \\
78\end{array}$ & $\begin{array}{l}255,092 \\
142,630 \\
112,462\end{array}$ & $\begin{array}{r}11,885 \\
1,441\end{array}$ & $8.24 *$ \\
\hline Rabbit & $\begin{array}{l}\text { Total } \\
\text { Among counties } \\
\text { Within counties }\end{array}$ & $\begin{array}{l}90 \\
12 \\
78\end{array}$ & $\begin{array}{l}613,030 \\
406,766 \\
206,264\end{array}$ & $\begin{array}{r}33,897 \\
2,644\end{array}$ & $12.82^{*}$ \\
\hline Quail & $\begin{array}{l}\text { Total } \\
\text { Among counties } \\
\text { Within counties }\end{array}$ & $\begin{array}{l}90 \\
12 \\
78\end{array}$ & $\begin{array}{l}233,570 \\
101,150 \\
132,420\end{array}$ & $\begin{array}{l}8,429 \\
1,697\end{array}$ & $4.96^{*}$ \\
\hline $\begin{array}{l}\text { Wild } \\
\text { Turkey }\end{array}$ & $\begin{array}{l}\text { Total } \\
\text { Among counties } \\
\text { Within counties }\end{array}$ & $\begin{array}{l}90 \\
12 \\
78\end{array}$ & $\begin{array}{l}404,396 \\
223,858 \\
180,537\end{array}$ & $\begin{array}{r}18,654 \\
2,314\end{array}$ & $8.06^{*}$ \\
\hline Bear & $\begin{array}{l}\text { Total } \\
\text { Among counties } \\
\text { Within counties }\end{array}$ & $\begin{array}{l}90 \\
12 \\
78\end{array}$ & $\begin{array}{r}421,212 \\
335,908 \\
85,304\end{array}$ & $\begin{array}{r}27,992 \\
1,093\end{array}$ & $25.60^{*}$ \\
\hline Raccoon & $\begin{array}{l}\text { Total } \\
\text { Among counties } \\
\text { Within counties }\end{array}$ & $\begin{array}{l}90 \\
12 \\
78\end{array}$ & $\begin{array}{l}519,459 \\
284,654 \\
234,804\end{array}$ & $\begin{array}{r}23,721 \\
3,010\end{array}$ & $7.88^{*}$ \\
\hline Groundhog & $\begin{array}{l}\text { Total } \\
\text { Among counties } \\
\text { Within counties }\end{array}$ & $\begin{array}{l}90 \\
12 \\
78\end{array}$ & $\begin{array}{r}1,470,939 \\
961,343 \\
509,596\end{array}$ & $\begin{array}{r}80,111 \\
6.533\end{array}$ & $12.26^{*}$ \\
\hline
\end{tabular}

*Significantly different at the 95 and 99 percentile levels than the theoretical $F$ values of $\mathrm{F}_{95} \stackrel{\text { Significan }}{=} 1.83$ and $\mathrm{F}_{99}=2.41$. 
TABLE 23

\section{Quality Evaluations for Hunting on Farm and Non-Farm Lands, By Kind of Wildlife, Berkeley County, West Virginia, Sample Survey of Landowners, 1965}

\begin{tabular}{llrrrrrrr}
\hline \hline $\begin{array}{l}\text { Kind of } \\
\text { Wildlife }\end{array}$ & $\begin{array}{l}\text { Land* } \\
\text { Category }\end{array}$ & $\begin{array}{c}\text { Excel- } \\
\text { lent }\end{array}$ & Good & Average & $\begin{array}{c}\text { Below } \\
\text { Average }\end{array}$ & Poor & None & $\begin{array}{c}\text { Don't } \\
\text { Know }\end{array}$ \\
\hline Squirrel & Farm & 0 & 12 & 11 & 3 & 12 & 7 & 7 \\
& Non-Farm & 0 & 5 & 8 & 3 & 6 & 3 & 4 \\
Rabbit & Farm & 2 & 15 & 20 & 1 & 6 & 1 & 2 \\
& Non-Farm & 1 & 5 & 9 & 6 & 1 & 3 & 4 \\
Ruffed & Farm & 0 & 3 & 6 & 3 & 7 & 25 & 3 \\
Grouse & Non-Farm & 0 & 1 & 7 & 3 & 2 & 11 & 5 \\
Deer & Farm & 0 & 9 & 10 & 6 & 13 & 7 & 2 \\
& Non-Farm & 0 & 5 & 7 & 4 & 2 & 6 & 5 \\
Wild & Farm & 0 & 0 & 1 & 0 & 0 & 44 & 2 \\
Turkey & Non-Farm & 0 & 1 & 1 & 1 & 1 & 20 & 5 \\
Quail & Farm & 1 & 21 & 18 & 1 & 4 & 0 & 2 \\
& Non-Farm & 0 & 4 & 11 & 2 & 0 & 7 & 5 \\
Raccoon & Farm & 6 & 5 & 13 & 3 & 5 & 12 & 3 \\
& Non-Farm & 0 & 4 & 5 & 5 & 1 & 9 & 5 \\
Bear & Farm & 0 & 0 & 0 & 0 & 1 & 44 & 2 \\
& Non-Farm & 0 & 0 & 0 & 0 & 0 & 24 & 5 \\
Groundhog & Farm & 30 & 10 & 4 & 1 & 0 & 0 & 2 \\
& Non-Farm & 8 & 9 & 4 & 1 & 1 & 1 & 5 \\
\hline
\end{tabular}

Chi-Square Test of Farm and Non-Farm Evaluations

\begin{tabular}{lcc}
\hline Wildlife & $\begin{array}{c}\text { Theoretical Value } \\
\text { of Chi-Square at } \\
\text { the 95\% Level }\end{array}$ & $\begin{array}{c}\text { Computed Value } \\
\text { of Chi-Square }\end{array}$ \\
\hline Squirrel & 12.592 & $6.07^{* *}$ \\
Rabbit & 12.592 & $17.02^{* * * *}$ \\
Ruffed Grouse & 12.592 & $6.01^{* * *}$ \\
Deer & 12.592 & $7.35^{* * *}$ \\
Wild Turkey & 12.592 & $3.07^{* * *}$ \\
Quail & 12.592 & $21.26^{* * * *}$ \\
Raccoon & 12.592 & $8.43^{* * *}$ \\
Bear & 12.592 & $2.06^{* * *}$ \\
Groundhog & 12.592 & $8.27^{* *}$ \\
\hline
\end{tabular}

*The sample includes 47 landowners whose lands are being farmed and 29 landowners whose lands are not being farmed.

**No apparent difference between farnı and non-farm evaluations.

***The differences between farm and non-farm landowner evaluations are of such magnitude that something other than chance is a contributing factor. 


\section{TABLE 24}

\section{Quality Evaluations for Hunting on Farm and Non-Farm Lands, By Kind of Wildlife, Hampshire County, West Virginia Sample Survey of Landowners, 1965}

\begin{tabular}{llccccccc}
\hline \hline $\begin{array}{l}\text { Kind of } \\
\text { Wildife }\end{array}$ & $\begin{array}{l}\text { Land* } \\
\text { Category }\end{array}$ & $\begin{array}{c}\text { Excel- } \\
\text { lent }\end{array}$ & Good & Average & $\begin{array}{c}\text { Below } \\
\text { Average }\end{array}$ & Poor & None & $\begin{array}{c}\text { Don't } \\
\text { Know }\end{array}$ \\
\hline Squirrel & Farm & 5 & 23 & 37 & 4 & 2 & 0 & 0 \\
& Non-Farm & 2 & 26 & 22 & 7 & 4 & 4 & 2 \\
Rabbit & Farm & 6 & 30 & 21 & 6 & 8 & 0 & 0 \\
& Non-Farm & 3 & 35 & 17 & 6 & 5 & 0 & 1 \\
Ruffed & Farm & 2 & 13 & 22 & 10 & 11 & 12 & 1 \\
Grouse & Non-Farm & 1 & 10 & 15 & 12 & 4 & 23 & 2 \\
Deer & Farm & 23 & 32 & 15 & 0 & 1 & 0 & 0 \\
& Non-Farm & 16 & 35 & 10 & 2 & 1 & 2 & 1 \\
WiId & Farm & 3 & 9 & 16 & 6 & 13 & 24 & 0 \\
Turkey & Non-Farm & 2 & 11 & 10 & 7 & 5 & 31 & 1 \\
Quail & Farm & 3 & 26 & 23 & 5 & 9 & 4 & 1 \\
& Non-Farm & 2 & 23 & 14 & 12 & 7 & 7 & 2 \\
Raccoon & Farm & 3 & 36 & 17 & 1 & 5 & 6 & 3 \\
& Non-Farm & 4 & 24 & 16 & 2 & 4 & 14 & 3 \\
Bear & Farm & 0 & 0 & 1 & 2 & 5 & 63 & 0 \\
& Non-Farm & 0 & 0 & 2 & 0 & 2 & 61 & 2 \\
Groundhog & Farm & 37 & 27 & 5 & 1 & 1 & 0 & 0 \\
& Non-Farm & 21 & 34 & 5 & 1 & 1 & 4 & 1 \\
\hline
\end{tabular}

Chi-Square Test of Farm and Non-Farm Evaluations

\begin{tabular}{lcc}
\hline Wildlife & $\begin{array}{c}\text { Theoretical Value } \\
\text { of Chi-Square at } \\
\text { the 95\% Level }\end{array}$ & $\begin{array}{c}\text { Computed Value } \\
\text { of Chi-Square }\end{array}$ \\
\hline Squirrel & 12.592 & $11.96^{* * *}$ \\
Rabbit & 12.592 & $4.18^{* * *}$ \\
Ruffed Grouse & 12.592 & $9.90^{* *}$ \\
Deer & 12.592 & $7.07^{* *}$ \\
Wild Turkey & 12.592 & $8.30^{* *}$ \\
Quail & 12.592 & $8.50^{* *}$ \\
Raccoon & 12.592 & $7.90^{* *}$ \\
Bear & 12.592 & $5.57^{* * *}$ \\
Groundhog & 12.592 & $9.80^{* *}$ \\
\hline
\end{tabular}

*The sample includes 71 landowners whose lands are being farmed and 67 landowners whose lands are not being farmed.

**No apparent difference between farm and non-farm evaluations. 
TABLE 25

\section{Quality Evaluations for Hunting on Farm and Non-Farm Lands, By Kind of Wildlife, Monroe County, West Yirginia, Sample Survey of Landowners, 1965}

\begin{tabular}{llccccccc}
\hline \hline $\begin{array}{l}\text { Kind of } \\
\text { Wildlife }\end{array}$ & $\begin{array}{c}\text { Land* } \\
\text { Category }\end{array}$ & $\begin{array}{c}\text { Excel- } \\
\text { lent }\end{array}$ & Good & Average & $\begin{array}{c}\text { Below } \\
\text { Average }\end{array}$ & Poor & None & $\begin{array}{c}\text { Don't } \\
\text { Know }\end{array}$ \\
\hline Squirrel & Farm & 1 & 21 & 15 & 6 & 8 & 4 & 1 \\
& Non-Farm & 4 & 11 & 14 & 9 & 5 & 5 & 3 \\
Rabbit & Farm & 0 & 23 & 20 & 7 & 4 & 1 & 1 \\
& Non-Farm & 3 & 18 & 15 & 7 & 4 & 2 & 2 \\
Ruffed & Farm & 0 & 15 & 14 & 9 & 1 & 14 & 3 \\
Grouse & Non-Farm & 1 & 8 & 11 & 7 & 1 & 19 & 4 \\
Deer & Farm & 1 & 10 & 11 & 3 & 5 & 23 & 3 \\
& Non-Farm & 1 & 8 & 6 & 8 & 5 & 20 & 3 \\
Wild & Farm & 0 & 2 & 8 & 1 & 3 & 38 & 4 \\
Turkey & Non-Farm & 0 & 1 & 1 & 4 & 3 & 38 & 4 \\
Quail & Farm & 1 & 13 & 19 & 10 & 3 & 6 & 4 \\
& Non-Farm & 1 & 9 & 12 & 9 & 2 & 13 & 5 \\
Raccoon & Farm & 1 & 8 & 14 & 11 & 3 & 14 & 5 \\
& Non-Farm & 0 & 6 & 12 & 7 & 1 & 22 & 3 \\
Bear & Farm & 0 & 2 & 0 & 0 & 0 & 48 & 6 \\
& Non-Farm & 0 & 0 & 0 & 1 & 2 & 65 & 3 \\
Groundhog & Farm & 9 & 32 & 8 & 2 & 0 & 3 & 2 \\
& Non-Farm & 6 & 20 & 12 & 2 & 2 & 4 & 5 \\
\hline
\end{tabular}

Chi-Square Test of Farm and Non-Farm Evaluations

\begin{tabular}{lcc}
\hline Wildlife & $\begin{array}{c}\text { Theoretical Value } \\
\text { of Chi-Square at } \\
\text { the 95\% Level }\end{array}$ & $\begin{array}{c}\text { Computed Value } \\
\text { of Chi-Square }\end{array}$ \\
\hline Squirrel & 12.592 & $6.25^{* *}$ \\
Rabbit & 12.592 & $4.02^{* *}$ \\
Ruffed Grouse & 12.592 & $4.34^{* *}$ \\
Deer & 12.592 & $4.51^{* *}$ \\
Wild Turkey & 12.592 & $8.55^{* *}$ \\
Quail & 12.592 & $5.65^{* *}$ \\
Raccoon & 12.592 & $6.38^{* *}$ \\
Bear & 12.592 & $6.45^{* *}$ \\
Groundhog & 12.592 & $6.37^{* *}$ \\
\hline
\end{tabular}

*The sample includes 56 landowners whose lands are being farmed and 51 landowners whose lands are not being farmed.

**No apparent difference between farm and non-farm evaluations. 
TABLE 26

\section{Quality Evaluations for Hunting on Farm and Non-Farm Lands, By Kind of Wildlife, Pendleton County, West Virginia, Sample Survey of Landowners, 1965}

\begin{tabular}{|c|c|c|c|c|c|c|c|c|}
\hline $\begin{array}{l}\text { Kind of } \\
\text { Wildlife }\end{array}$ & $\begin{array}{c}\text { Land* } \\
\text { Category }\end{array}$ & $\begin{array}{r}\text { Excel- } \\
\text { lent }\end{array}$ & Good & Average & $\begin{array}{c}\text { Below } \\
\text { Average }\end{array}$ & Poor & None & $\begin{array}{l}\text { Don't } \\
\text { Know }\end{array}$ \\
\hline \multirow[t]{2}{*}{ Squirrel } & Farm & 8 & 23 & 18 & 4 & 5 & 2 & 0 \\
\hline & Non-Farm & 4 & 26 & 13 & 1 & 2 & 1 & \\
\hline \multirow[t]{2}{*}{ Rabbit } & Farm & 2 & 21 & 15 & 12 & 8 & 2 & 0 \\
\hline & Non-Farm & 0 & 15 & & 10 & 7 & 4 & 0 \\
\hline & Farm & 2 & 19 & 10 & $1 \mathrm{I}$ & 7 & 11 & 0 \\
\hline Grouse & Non-Farm & 0 & 20 & 9 & 5 & 1 & 12 & 0 \\
\hline \multirow[t]{2}{*}{ Deer } & Farm & 7 & 26 & 16 & 3 & 3 & 3 & 0 \\
\hline & Non-Farm & 2 & 25 & 14 & 2 & 1 & 3 & 0 \\
\hline Wild & Farm & 3 & 22 & 12 & 6 & 4 & 13 & 0 \\
\hline Turkey & Non-Farm & 1 & 21 & 8 & 6 & 2 & 9 & 0 \\
\hline \multirow[t]{2}{*}{ Quail } & Farm & 1 & 10 & 7 & 11 & 9 & 22 & 0 \\
\hline & Non-Farm & 0 & 11 & 9 & 3 & 5 & 19 & 0 \\
\hline \multirow[t]{2}{*}{ Raccoon } & Farm & 7 & 23 & 10 & 5 & 3 & 12 & 0 \\
\hline & Non-Farm & 2 & 28 & 11 & 1 & 1 & 4 & 0 \\
\hline \multirow[t]{2}{*}{ Bear } & Farm & 1 & 4 & 5 & 7 & 4 & 30 & 0 \\
\hline & Non-Farm & 0 & 10 & 5 & 5 & 5 & 22 & 0 \\
\hline \multirow[t]{2}{*}{ Groundhog } & Farm & 9 & 44 & 6 & 0 & 1 & 0 & 0 \\
\hline & Non-Farm & 25 & 10 & 8 & 2 & 2 & 0 & 0 \\
\hline
\end{tabular}

Chi-Square Test of Farm and Non-Farm Evaluations

\begin{tabular}{lcc}
\hline Wildlife & $\begin{array}{c}\text { Theoretical Value } \\
\text { of Chi-Square at } \\
\text { the } \mathbf{9 5 \%} \text { Level }\end{array}$ & $\begin{array}{c}\text { Computed Value } \\
\text { of Chi-Square }\end{array}$ \\
\hline Squirrel & 12.592 & $3.05^{* *}$ \\
Rabbit & 12.592 & $3.07^{* *}$ \\
Ruffed Grouse & 12.592 & $8.03^{* * *}$ \\
Deer & 12.592 & $3.04^{* * *}$ \\
Wild Turkey & 12.592 & $2.05^{* *}$ \\
Quail & 12.592 & $4.09^{* *}$ \\
Raccoon & 12.592 & $9.07^{* *}$ \\
Bear & 12.592 & $6.08^{* *}$ \\
Groundhog & 12.592 & $31.33^{* * *}$ \\
\hline
\end{tabular}

*The sample includes 60 landowners whose lands are being farmed and 47 landowners whose lands are not being farmed.

**The apparent difference between farm and non-farm evaluations.

***The differences between farm and non-farm landowner evaluations are of such magnitude that something other than chance is a contributing factor. 
TABLE 27

Quality Evaluations for Hunting on Farm and Non-Farm Lands, By Kind of Wildlife, Pocahontas County, West Virginia, Sample Survey of Landowners, 1965

\begin{tabular}{llrrrrrrr}
\hline \hline $\begin{array}{l}\text { Kind of } \\
\text { Wildlife }\end{array}$ & $\begin{array}{c}\text { Land* } \\
\text { Category }\end{array}$ & $\begin{array}{c}\text { Excel- } \\
\text { lent }\end{array}$ & Good & Average & $\begin{array}{c}\text { Below } \\
\text { Average }\end{array}$ & Poor & None & $\begin{array}{c}\text { Don't } \\
\text { Know }\end{array}$ \\
\hline Squirrel & Farm & 0 & 18 & 14 & 6 & 7 & 3 & 0 \\
& Non-Farm & 2 & 8 & 12 & 8 & 8 & 4 & 1 \\
Rabbit & Farm & 1 & 12 & 19 & 7 & 6 & 3 & 0 \\
& Non-Farm & 2 & 7 & 9 & 10 & 8 & 5 & 2 \\
Ruffed & Farm & 1 & 9 & 22 & 7 & 3 & 5 & 1 \\
Grouse & Non-Farm & 2 & 7 & 12 & 7 & 4 & 7 & 4 \\
Deer & Farm & 1 & 9 & 15 & 4 & 2 & 16 & 1 \\
& Non-Farm & 2 & 8 & 12 & 5 & 5 & 11 & 0 \\
Wild & Farm & 1 & 5 & 9 & 7 & 1 & 25 & 0 \\
Turkey & Non-Farm & 1 & 6 & 5 & 5 & 3 & 22 & 1 \\
Quail & Farm & 0 & 4 & 13 & 8 & 4 & 19 & 0 \\
& Non-Farm & 1 & 5 & 2 & 7 & 8 & 18 & 2 \\
Raccoon & Farm & 1 & 16 & 15 & 4 & 1 & 9 & 2 \\
& Non-Farm & 1 & 7 & 9 & 9 & 2 & 14 & 1 \\
Bear & Farm & 0 & 3 & 8 & 3 & 1 & 32 & 1 \\
& Non-Farm & 1 & 1 & 4 & 5 & 3 & 29 & 0 \\
Groundhog & Farm & 11 & 27 & 4 & 4 & 0 & 0 & 2 \\
& Non-Farm & 12 & 15 & 8 & 2 & 3 & $\mathbf{2}$ & 1 \\
\hline
\end{tabular}

Chi-Square Test of Farm and Non-Farm Evaluations

\begin{tabular}{lcc}
\hline Wildlife & $\begin{array}{c}\text { Theoretical Value } \\
\text { of Chi-Square at } \\
\text { the 95\% Level }\end{array}$ & $\begin{array}{c}\text { Computed Value } \\
\text { of Chi-Square }\end{array}$ \\
\hline Squirrel & 12.592 & $5.82^{* *}$ \\
Rabbit & 12.592 & $8.34^{* *}$ \\
Ruffed Grouse & 12.592 & $6.47^{* *}$ \\
Deer & 12.592 & $4.55^{* *}$ \\
Wild Turkey & 12.592 & $2.44^{* *}$ \\
Quail & 12.592 & $10.67^{* *}$ \\
Raccoon & 12.592 & $10.15^{* *}$ \\
Bear & 12.592 & $3.09^{* *}$ \\
Groundhog & 12.592 & $12.57^{* *}$ \\
\hline
\end{tabular}

*The sample includes 48 landowners whose lands are being farmed and 43 landowners whose lands are not being farmed.

**No apparent differences between farm and non-farm evaluations. 


\section{TABLE 28}

Quality Evaluations for Hunting on Farm and Non-Farm Lands, By Kind of Wildlife, Preston County, West Virginia, Sample Survey of Landowners, 1965

\begin{tabular}{llrrrrrrr}
\hline \hline $\begin{array}{l}\text { Kind of } \\
\text { Wildlife }\end{array}$ & $\begin{array}{c}\text { Land* } \\
\text { Category }\end{array}$ & $\begin{array}{r}\text { Excel- } \\
\text { lent }\end{array}$ & Good & Average & $\begin{array}{c}\text { Below } \\
\text { Average }\end{array}$ & Poor & None & $\begin{array}{c}\text { Don't } \\
\text { Know }\end{array}$ \\
\hline Squirrel & Farm & 0 & 20 & 19 & 8 & 11 & 5 & 1 \\
& Non-Farm & 5 & 32 & 30 & 13 & 11 & 11 & 8 \\
Rabbit & Farm & 5 & 23 & 20 & 7 & 4 & 4 & 1 \\
& Non-Farm & 5 & 36 & 26 & 13 & 12 & 9 & 9 \\
Ruffed & Farm & 1 & 12 & 13 & 15 & 12 & 9 & 2 \\
Grouse & Non-Farm & 2 & 25 & 22 & 8 & 16 & 27 & 10 \\
Deer & Farm & 3 & 24 & 21 & 5 & 5 & 5 & 1 \\
& Non-Farm & 4 & 38 & 31 & 8 & 9 & 12 & 8 \\
Wild & Farm & 0 & 0 & 0 & 0 & 3 & 60 & 1 \\
Turkey & Non-Farm & 0 & 0 & 0 & 3 & 9 & 89 & 9 \\
Quail & Farm & 0 & 7 & 2 & 6 & 12 & 36 & 1 \\
& Non-Farm & 0 & 10 & 10 & 14 & 10 & 54 & 12 \\
Raccoon & Farm & 4 & 18 & 18 & 5 & 3 & 15 & 1 \\
& Non-Farm & 5 & 28 & 26 & 6 & 7 & 28 & 10 \\
Bear & Farm & 0 & 0 & 0 & 0 & 1 & 62 & 1 \\
& Non-Farm & 0 & 0 & 0 & 0 & 2 & 100 & 8 \\
Groundhog & Farm & 37 & 22 & 5 & 0 & 0 & 0 & 0 \\
& Non-Farm & 32 & 47 & 10 & 4 & 3 & 4 & 10 \\
\hline & & & & & & & &
\end{tabular}

Chi-Square Test of Farm and Non-Farm Evaluations

\begin{tabular}{lcc}
\hline Wildlife & $\begin{array}{c}\text { Theoretical Value } \\
\text { of Chi-Square at } \\
\text { the 95\% Level }\end{array}$ & $\begin{array}{c}\text { Computed Value } \\
\text { of Chi-Square }\end{array}$ \\
\hline Squirrel & 12.592 & $7.76^{* * *}$ \\
Rabbit & 12.592 & $6.12^{* * *}$ \\
Ruffed Grouse & 12.592 & $12.97^{* * *}$ \\
Deer & 12.592 & $3.01^{* * *}$ \\
Wild Turkey & 12.592 & $5.52^{* *}$ \\
Quail & 12.592 & $10.07^{* *}$ \\
Raccoon & 12.592 & $5.36^{* * *}$ \\
Bear & 12.592 & $2.08^{* *}$ \\
Groundhog & 12.592 & $21.70^{* * *}$ \\
\hline
\end{tabular}

*The sample includes 64 landowners whose lands are being farmed and 110 landowners whose lands are not being farmed.

**No apparent difference between farm and non-farm evaluations.

***The differences between farm and non-farm landowner evaluations are of sucn magnitude that something other than chance is a contributing factor. 
TABLE 29

Quality Evaluations for Hunting on Farm and Non-Farm Lands, By Kind of Wildlife, Fayette County, West Virginia, Sample Survey of Landowners, 1965

\begin{tabular}{llccccccc}
\hline \hline $\begin{array}{l}\text { Kind of } \\
\text { Wildlife }\end{array}$ & $\begin{array}{c}\text { Land* } \\
\text { Category }\end{array}$ & $\begin{array}{c}\text { Excel- } \\
\text { lent }\end{array}$ & Good & Average & $\begin{array}{c}\text { Below } \\
\text { Average }\end{array}$ & Poor & None & $\begin{array}{c}\text { Don't } \\
\text { Know }\end{array}$ \\
\hline Squirrel & Farm & 0 & 3 & 4 & 1 & 0 & 1 & 0 \\
& Non-Farm & 2 & 11 & 13 & 2 & 2 & 7 & 2 \\
Rabbit & Farm & 0 & 3 & 5 & 1 & 0 & 0 & 0 \\
& Non-Farm & 5 & 9 & 12 & 5 & 5 & 1 & 2 \\
Ruffed & Farm & 0 & 2 & 2 & 2 & 1 & 2 & 0 \\
Grouse & Non-Farm & 3 & 4 & 10 & 5 & 3 & 11 & 3 \\
Deer & Farm & 1 & 2 & 1 & 2 & 0 & 3 & 0 \\
& Non-Farm & 3 & 5 & 9 & 1 & 5 & 13 & 3 \\
Wild & Farm & 0 & 0 & 0 & 0 & 0 & 9 & 0 \\
Turkey & Non-Farm & 2 & 0 & 2 & 4 & 0 & 28 & 3 \\
Quail & Farm & 0 & 0 & 3 & 4 & 0 & 2 & 0 \\
& Non-Farm & 2 & 2 & 9 & 6 & 8 & 8 & 4 \\
Raccoon & Farm & 0 & 1 & 3 & 0 & 1 & 4 & 0 \\
& Non-Farm & 2 & 3 & 13 & 5 & 5 & 8 & 3 \\
Bear & Farm & 0 & 0 & 0 & 0 & 0 & 9 & 0 \\
& Non-Farm & 0 & 0 & 0 & 3 & 2 & 31 & 3 \\
Groundhog & Farm & 2 & 1 & 4 & 0 & 0 & 2 & 0 \\
& Non-Farm & 9 & 10 & 9 & 2 & 2 & 4 & 3 \\
\hline
\end{tabular}

Chi-Square Test of Farm and Non-Farm Evaluations

\begin{tabular}{lcc}
\hline Wildlife & $\begin{array}{c}\text { Theoretical Value } \\
\text { of Chi-Square at } \\
\text { the 95\% Level }\end{array}$ & $\begin{array}{c}\text { Computed Value } \\
\text { of Chi-Square }\end{array}$ \\
\hline Squirrel & 12.592 & $1.00^{* *}$ \\
Rabbit & 12.592 & $4.07^{* *}$ \\
Ruffed Grouse & 12.592 & $5.03^{* *}$ \\
Deer & 12.592 & $6.00^{* *}$ \\
Wild Turkey & 12.592 & $3.00^{* *}$ \\
Quail & 12.592 & $6.05^{* *}$ \\
Raccoon & 12.592 & $5.00^{* *}$ \\
Bear & 12.592 & $3.07^{* *}$ \\
Groundhog & 12.592 & $5.07^{* *}$ \\
\hline
\end{tabular}

*The sample includes 9 landowners whose lands are being farmed and 39 landowners whose lands are not being farmed.

**No apparent difference between farm and non-farm evaluations. 
TABLE 30

Quality Evaluations for Hunting on Farm and Non-Farm Lands,
By Kind of Wildlife, Lincoln County, West Virginia,
Sample Survey of Landowners, 1965

\begin{tabular}{llrrrrrrr}
\hline \hline $\begin{array}{l}\text { Kind of } \\
\text { Wildlife }\end{array}$ & $\begin{array}{l}\text { Land* } \\
\text { Category }\end{array}$ & $\begin{array}{c}\text { Excel- } \\
\text { lent }\end{array}$ & Good & Average & $\begin{array}{r}\text { Below } \\
\text { Average }\end{array}$ & Poor & None & $\begin{array}{r}\text { Don't } \\
\text { Know }\end{array}$ \\
\hline Squirrel & Farm & 0 & 9 & 17 & 5 & 7 & 0 & 1 \\
& Non-Farm & 0 & 15 & 35 & 20 & 6 & 0 & 17 \\
Rabbit & Farm & 0 & 7 & 14 & 7 & 8 & 1 & 2 \\
& Non-Farm & 0 & 9 & 31 & 26 & 9 & 2 & 16 \\
Ruffed & Farm & 0 & 4 & 10 & 10 & 8 & 4 & 3 \\
Grouse & Non-Farm & 0 & 6 & 16 & 18 & 11 & 19 & 23 \\
Deer & Farm & 0 & 3 & 7 & 5 & 6 & 14 & 4 \\
& Non-Farm & 0 & 1 & 6 & 9 & 12 & 41 & 24 \\
Wild & Farm & 0 & 0 & 0 & 1 & 0 & 35 & 3 \\
Turkey & Non-Farm & 0 & 0 & 0 & 0 & 0 & 71 & 22 \\
Quail & Farm & 0 & 5 & 6 & 8 & 8 & 10 & 2 \\
& Non-Farm & 0 & 4 & 16 & 12 & 13 & 27 & 21 \\
Raccoon & Farm & 0 & 4 & 13 & 7 & 3 & 8 & 4 \\
& Non-Farm & 0 & 4 & 20 & 14 & 9 & 21 & 25 \\
Bear & Farm & 0 & 0 & 0 & 0 & 1 & 35 & 3 \\
& Non-Farm & 0 & 0 & 0 & 0 & 0 & 70 & 23 \\
Groundhog & Farm & 3 & 13 & 16 & 3 & 0 & 2 & 2 \\
& Non-Farm & 1 & 3 & 28 & 8 & 6 & 6 & 21 \\
\hline
\end{tabular}

Chi-Square Test of Farm and Non-Farm Evaluations

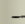

Wildlife
$\begin{gathered}\text { Theoretical Value } \\ \text { of Chi-Square at } \\ \text { the } 95 \% \text { Level }\end{gathered}$

Computed Value of Chi-Square

Squirrel

12.592

12.592

12.592

12.592

Ruffed Grouse

12.592

12.592

12.592

I 2.592

12.592

* The sample includes 39 landowners whose lands are being farmed and 93 landowners whose lands are not being farmed.

* No apparent difference between farm and non-farm evaluations.

***The differences between farm and non-farm landowner 
TABLE 31

\section{Quality Evaluations for Hunting on Farm and Non-Form Lands, By Kind of Wildlife, Wyoming County, West Virginio, Sample Survey of Landowners, 1965}

\begin{tabular}{llllccccc}
\hline \hline $\begin{array}{l}\text { Kind of } \\
\text { Wildlife }\end{array}$ & $\begin{array}{c}\text { Land* } \\
\text { Category }\end{array}$ & $\begin{array}{c}\text { Excel- } \\
\text { lent }\end{array}$ & Good & Average & $\begin{array}{c}\text { Below } \\
\text { Average }\end{array}$ & Poor & None & $\begin{array}{c}\text { Don't } \\
\text { Know }\end{array}$ \\
\hline Squirrel & Farm & 0 & 0 & 2 & 1 & 2 & 1 & 0 \\
& Non-Farm & 2 & 7 & 9 & 4 & 2 & 3 & 0 \\
Rabbit & Farm & 0 & 1 & 3 & 1 & 1 & 0 & 0 \\
& Non-Farm & 2 & 8 & 11 & 3 & 2 & 1 & 0 \\
Ruffed & Farm & 0 & 0 & 2 & 3 & 0 & 1 & 0 \\
Grouse & Non-Farm & 0 & 6 & 8 & 1 & 2 & 10 & 0 \\
Deer & Farm & 0 & 0 & 2 & 0 & 0 & 4 & 0 \\
& Non-Farm & 0 & 2 & 5 & 1 & 1 & 18 & 0 \\
Wild & Farm & 0 & 0 & 0 & 0 & 0 & 6 & 0 \\
Turkey & Non-Farm & 0 & 0 & 1 & 0 & 0 & 26 & 0 \\
Quail & Farm & 0 & 0 & 3 & 1 & 0 & 2 & 0 \\
& Non-Farm & 0 & 2 & 5 & 3 & 4 & 13 & 0 \\
Raccoon & Farm & 0 & 0 & 3 & 0 & 0 & 3 & 0 \\
& Non-Farm & 0 & 2 & 4 & 3 & 1 & 16 & 1 \\
Bear & Farm & 0 & 0 & 0 & 0 & 0 & 6 & 0 \\
& Non-Farm & 0 & 0 & 1 & 0 & 2 & 14 & 0 \\
Groundhog & Farm & 0 & 1 & 4 & 1 & 0 & 0 & 0 \\
& Non-Farm & 3 & 6 & 10 & 2 & 2 & 3 & 1 \\
\hline & & & & & & & &
\end{tabular}

Chi-Square Test of Farm and Non-Farm Evaluations

\begin{tabular}{lcc}
\hline Wildlife & $\begin{array}{c}\text { Theoretical Value } \\
\text { of Chi-Square at } \\
\text { the 95\% Level }\end{array}$ & $\begin{array}{c}\text { Computed Value } \\
\text { of Chi-Square }\end{array}$ \\
\hline Squirrel & 12.592 & $1.16^{* *}$ \\
Rabbit & 12.592 & $0.70^{* *}$ \\
Ruffed Grouse & 12.592 & $7.10^{* *}$ \\
Deer & 12.592 & $1.10^{* *}$ \\
Wild Turkey & 12.592 & $0.00^{* *}$ \\
Quail & 12.592 & $5.80^{* *}$ \\
Raccoon & 12.592 & $6.20^{* * *}$ \\
Bear & 12.592 & $0.30^{* * *}$ \\
Groundhog & 12.592 & $3.20^{* *}$ \\
\hline
\end{tabular}

*The sample includes 6 landowners whose lands are being farmed and 27 landowners whose lands are not being farmed.

**No apparent difference between farm and non-farm evaluations. 


\section{TABLE 32}

\section{Quality Evaluations for Hunting on Farm and Non-Farm Lands, By Kind of Wildlife, Braxton County, West Virginia, Sample Survey of Landowners, 1965}

\begin{tabular}{|c|c|c|c|c|c|c|c|c|}
\hline $\begin{array}{l}\text { Kind of } \\
\text { Wildlife }\end{array}$ & $\begin{array}{c}\text { Land* } \\
\text { Category }\end{array}$ & $\begin{array}{r}\text { Excel- } \\
\text { lent }\end{array}$ & Good & Average & $\begin{array}{c}\text { Below } \\
\text { Average }\end{array}$ & Poor & None & $\begin{array}{l}\text { Don't } \\
\text { Know }\end{array}$ \\
\hline$\overline{\text { Squirrel }}$ & $\begin{array}{l}\text { Farm } \\
\text { Non-Farm }\end{array}$ & $\begin{array}{r}2 \\
10\end{array}$ & $\begin{array}{l}30 \\
23\end{array}$ & $\begin{array}{l}17 \\
23\end{array}$ & $\begin{array}{l}2 \\
4\end{array}$ & $\begin{array}{l}1 \\
5\end{array}$ & $\begin{array}{l}1 \\
2\end{array}$ & $\begin{array}{r}3 \\
11\end{array}$ \\
\hline Rabbit & $\begin{array}{l}\text { Farm } \\
\text { Non-Farm }\end{array}$ & $\begin{array}{l}2 \\
7\end{array}$ & $\begin{array}{l}10 \\
12\end{array}$ & $\begin{array}{l}26 \\
26\end{array}$ & $\begin{array}{r}9 \\
13\end{array}$ & $\begin{array}{l}6 \\
7\end{array}$ & $\begin{array}{l}0 \\
3\end{array}$ & $\begin{array}{r}3 \\
10\end{array}$ \\
\hline $\begin{array}{l}\text { Ruffed } \\
\text { Grouse }\end{array}$ & $\begin{array}{l}\text { Farm } \\
\text { Non-Farm }\end{array}$ & $\begin{array}{l}0 \\
0\end{array}$ & $\begin{array}{l}8 \\
8\end{array}$ & $\begin{array}{r}9 \\
22\end{array}$ & $\begin{array}{r}16 \\
9\end{array}$ & $\begin{array}{l}12 \\
11\end{array}$ & $\begin{array}{r}5 \\
15\end{array}$ & $\begin{array}{r}6 \\
13\end{array}$ \\
\hline Deer & $\begin{array}{l}\text { Farm } \\
\text { Non-Farm }\end{array}$ & $\begin{array}{l}0 \\
4\end{array}$ & $\begin{array}{l}12 \\
11\end{array}$ & $\begin{array}{l}23 \\
24\end{array}$ & $\begin{array}{r}9 \\
10\end{array}$ & $\begin{array}{l}3 \\
9\end{array}$ & $\begin{array}{l}2 \\
9\end{array}$ & $\begin{array}{r}7 \\
11\end{array}$ \\
\hline $\begin{array}{l}\text { Wild } \\
\text { Turkey }\end{array}$ & $\begin{array}{l}\text { Farm } \\
\text { Non-Farm }\end{array}$ & $\begin{array}{l}0 \\
0\end{array}$ & $\begin{array}{l}1 \\
1\end{array}$ & $\begin{array}{l}1 \\
0\end{array}$ & $\begin{array}{l}0 \\
0\end{array}$ & $\begin{array}{l}0 \\
0\end{array}$ & $\begin{array}{l}47 \\
66\end{array}$ & $\begin{array}{r}7 \\
11\end{array}$ \\
\hline Quail & $\begin{array}{l}\text { Farm } \\
\text { Non-Farm }\end{array}$ & $\begin{array}{l}0 \\
0\end{array}$ & $\begin{array}{l}5 \\
6\end{array}$ & $\begin{array}{l}10 \\
12\end{array}$ & $\begin{array}{l}13 \\
10\end{array}$ & $\begin{array}{l}13 \\
16\end{array}$ & $\begin{array}{r}8 \\
21\end{array}$ & $\begin{array}{r}7 \\
13\end{array}$ \\
\hline Raccoon & $\begin{array}{l}\text { Farm } \\
\text { Non-Farm }\end{array}$ & $\begin{array}{l}5 \\
8\end{array}$ & $\begin{array}{l}18 \\
13\end{array}$ & $\begin{array}{l}15 \\
17\end{array}$ & $\begin{array}{r}4 \\
14\end{array}$ & $\begin{array}{l}2 \\
2\end{array}$ & $\begin{array}{r}6 \\
10\end{array}$ & $\begin{array}{r}6 \\
14\end{array}$ \\
\hline Bear & $\begin{array}{l}\text { Farm } \\
\text { Non-Farm }\end{array}$ & $\begin{array}{l}0 \\
0\end{array}$ & $\begin{array}{l}0 \\
0\end{array}$ & $\begin{array}{l}0 \\
0\end{array}$ & $\begin{array}{l}0 \\
0\end{array}$ & $\begin{array}{l}3 \\
1\end{array}$ & $\begin{array}{l}46 \\
64\end{array}$ & $\begin{array}{r}7 \\
13\end{array}$ \\
\hline Groundhog & $\begin{array}{l}\text { Farm } \\
\text { Non-Farm }\end{array}$ & $\begin{array}{l}23 \\
\quad 23\end{array}$ & $\begin{array}{l}23 \\
29\end{array}$ & $\begin{array}{l}5 \\
9\end{array}$ & $\begin{array}{l}1 \\
2 \\
\end{array}$ & $\begin{array}{l}0 \\
1\end{array}$ & $\begin{array}{l}0 \\
1 \\
\end{array}$ & $\begin{array}{r}4 \\
13 \\
\end{array}$ \\
\hline
\end{tabular}

Chi-Square Test of Farm and Non-Farm Evaluations

\begin{tabular}{lcc}
\hline Wildlife & $\begin{array}{c}\text { Theoretical Value } \\
\text { of Chi-Square at } \\
\text { the 95\% Level }\end{array}$ & $\begin{array}{c}\text { Computed Value } \\
\text { of Chi-Square }\end{array}$ \\
\hline Squirrel & 12.592 & $12.75^{* * *}$ \\
Rabbit & 12.592 & $6.08^{* * *}$ \\
Ruffed Grouse & 12.592 & $10.04^{* *}$ \\
Deer & 12.592 & $9.75^{* *}$ \\
Wild Turkey & 12.592 & $1.01^{* *}$ \\
Quail & 12.592 & $4.55^{* *}$ \\
Raccoon & 12.592 & $8.07^{* *}$ \\
Bear & 12.592 & $1.02^{* *}$ \\
Groundhog & 12.592 & $6.02^{* *}$ \\
\hline
\end{tabular}

*The sample includes 56 landowners whose lands are being farmed and 78 landowners whose lands are not being farmed.

* No apparent difference between farm and non-farm evaluations.

***The differences between farm and non-farm landowner evaluations are of such magnitude that something other than chance is a contributing factor. 
TABLE 33

Quality Evaluations for Hunting on Farm and Non-Farm Lands, By Kind of Wildlife, Doddridge County, West Virginia, Sample Survey of Landowners, 1965

\begin{tabular}{lllcccccc}
\hline \hline $\begin{array}{l}\text { Kind of } \\
\text { Wildlife }\end{array}$ & $\begin{array}{c}\text { Land* } \\
\text { Category }\end{array}$ & $\begin{array}{c}\text { Excel- } \\
\text { lent }\end{array}$ & Good & Average & $\begin{array}{c}\text { Below } \\
\text { Average }\end{array}$ & Poor & None & $\begin{array}{c}\text { Don't } \\
\text { Know }\end{array}$ \\
\hline Squirrel & Farm & 6 & 14 & 17 & 3 & 3 & 3 & 2 \\
& Non-Farm & 5 & 13 & 16 & 1 & 0 & 1 & 7 \\
Rabbit & Farm & 1 & 12 & 16 & 7 & 6 & 3 & 3 \\
& Non-Farm & 1 & 8 & 12 & 9 & 4 & 1 & 8 \\
Ruffed & Farm & 0 & 6 & 9 & 9 & 11 & 11 & 2 \\
Grouse & Non-Farm & 2 & 4 & 9 & 5 & 3 & 11 & 9 \\
Deer & Farm & 1 & 14 & 17 & 6 & 1 & 7 & 2 \\
& Non-Farm & 3 & 10 & 11 & 8 & 0 & 3 & 8 \\
Wild & Farm & 0 & 1 & 1 & 0 & 3 & 41 & 2 \\
Turkey & Non-Farm & 0 & 0 & 0 & 0 & 2 & 33 & 8 \\
Quail & Farm & 0 & 7 & 4 & 5 & 10 & 20 & 2 \\
& Non-Farm & 1 & 5 & 6 & 5 & 3 & 14 & 9 \\
Raccoon & Farm & 6 & 19 & 9 & 6 & 1 & 5 & 2 \\
& Non-Farm & 3 & 16 & 6 & 2 & 3 & 5 & 8 \\
Bear & Farm & 0 & 0 & 0 & 0 & 0 & 47 & 1 \\
& Non-Farm & 0 & 0 & 0 & 0 & 1 & 34 & 8 \\
Groundhog & Farm & 25 & 16 & 2 & 0 & 1 & 1 & 3 \\
& Non-Farm & 18 & 11 & 4 & 1 & 1 & 1 & 7 \\
\hline & & & & & & & &
\end{tabular}

\section{Chi-Square Test of Farm and Non-Farm Evaluations}

\begin{tabular}{lcc}
\hline Wildlife & $\begin{array}{c}\text { Theoretical Value } \\
\text { of Chi-Square at } \\
\text { the 95\% Level }\end{array}$ & $\begin{array}{c}\text { Computed Value } \\
\text { of Chi-Square }\end{array}$ \\
\hline Squirrel & 12.592 & $11.15^{* *}$ \\
Rabbit & 12.592 & $5.06^{* * *}$ \\
Ruffed Grouse & 12.592 & $13.01^{* * *}$ \\
Deer & 12.592 & $8.01^{* *}$ \\
Wild Turkey & 12.592 & $4.03^{* *}$ \\
Quail & 12.592 & $9.08^{* *}$ \\
Raccoon & 12.592 & $7.35^{* * *}$ \\
Bear & 12.592 & $8.00^{* *}$ \\
Groundhog & 12.592 & $3.02^{* *}$ \\
\hline
\end{tabular}

*The sample includes 48 landowners whose lands are being farmed and 43 landowners whose lands are not being farmed.

** No apparent difference between farm and non-farm evaluations.

***The differences between farm and non-farm landowner evaluations are of such magnitude that something other than chance is a colltributing factor. 
TABLE 34

\section{Quality Evaluations for Hunting on Farm and Non-Farm Lands, By Kind of Wildlife, Marshall County, West Virginia, Sample Survey of Landowners, 1965}

\begin{tabular}{llccccccc}
\hline \hline $\begin{array}{l}\text { Kind of } \\
\text { Wildlife }\end{array}$ & $\begin{array}{l}\text { Land* } \\
\text { Category }\end{array}$ & $\begin{array}{r}\text { Excel- } \\
\text { lent }\end{array}$ & Good & Average & $\begin{array}{c}\text { Below } \\
\text { Average }\end{array}$ & Poor & None & $\begin{array}{r}\text { Don't } \\
\text { Know }\end{array}$ \\
\hline Squirrel & Farm & 2 & 7 & 25 & 11 & 9 & 0 & 3 \\
& Non-Farm & 2 & 19 & 22 & 5 & 11 & 2 & 15 \\
Rabbit & Farm & 2 & 12 & 25 & 11 & 3 & 1 & 3 \\
& Non-Farm & 2 & 20 & 22 & 10 & 7 & 0 & 15 \\
Ruffed & Farm & 2 & 5 & 16 & 18 & 8 & 5 & 3 \\
Grouse & Non-Farm & 2 & 7 & 17 & 13 & 12 & 10 & 15 \\
Deer & Farm & 0 & 4 & 21 & 17 & 9 & 3 & 3 \\
& Non-Farm & 1 & 5 & 20 & 12 & 19 & 3 & 16 \\
Wild & Farm & 0 & 0 & 0 & 0 & 1 & 55 & 1 \\
Turkey & Non-Farm & 0 & 0 & 0 & 0 & 0 & 67 & 9 \\
Quail & Farm & 1 & 2 & 11 & 14 & 9 & 12 & 8 \\
& Non-Farm & 0 & 5 & 14 & 14 & 9 & 16 & 18 \\
Raccoon & Farm & 12 & 13 & 23 & 3 & 2 & 1 & 3 \\
& Non-Farm & 3 & 28 & 22 & 3 & 3 & 1 & 16 \\
Bear & Farm & 0 & 0 & 0 & 0 & 1 & 55 & 1 \\
& Non-Farm & 0 & 0 & 0 & 0 & 0 & 65 & 10 \\
Groundhog & Farm & 39 & 12 & 4 & 0 & 0 & 0 & 2 \\
& Non-Farm & 27 & 22 & 8 & 1 & 1 & 0 & 17 \\
\hline & & & & & & & &
\end{tabular}

Chi-Square Test of Farm and Non-Farm Evaluations

\begin{tabular}{lcc}
\hline Wildlife & $\begin{array}{c}\text { Theoretical Value } \\
\text { of Chi-Square at } \\
\text { the 95\% Level }\end{array}$ & $\begin{array}{c}\text { Computed Value } \\
\text { of Chi-Square }\end{array}$ \\
\hline Squirrel & 12.592 & $14.34^{* * * *}$ \\
Rabbit & 12.592 & $10.02^{* *}$ \\
Ruffed Grouse & 12.592 & $8.82^{* *}$ \\
Deer & 12.592 & $11.66^{* *}$ \\
Wild Turkey & 12.592 & $6.03^{* *}$ \\
Quail & 12.592 & $3.75^{* *}$ \\
Raccoon & 12.592 & $18.35^{* * *}$ \\
Leer & 12.592 & $3.84^{* *}$ \\
Groundhog & 12.592 & $17.50^{* * *}$ \\
\hline
\end{tabular}

*The sample includes 57 landowners whose Iands are being farmed and 75 landowners whose lands are not being farmed.

* No apparent difference between farm and non-farm evaluations.

***The differences between farm and non-farm landowner evaluations are of such magnitude that something other than chance is a contributing factor. 
TABLE 35

Quality Evaluations for Hunting on Farm and Non-Farm Lands, By Kind of Wildlife, Roane County, West Virginio, Sample Survey of Landowners, 1965

\begin{tabular}{|c|c|c|c|c|c|c|c|c|}
\hline $\begin{array}{l}\text { Kind of } \\
\text { Wildlife }\end{array}$ & $\begin{array}{c}\text { Land* } \\
\text { Category }\end{array}$ & $\begin{array}{r}\text { Excel- } \\
\text { lent }\end{array}$ & Good & Average & $\begin{array}{c}\text { Below } \\
\text { Average }\end{array}$ & Poor & None & $\begin{array}{l}\text { Don't } \\
\text { Know }\end{array}$ \\
\hline Squirrel & $\begin{array}{l}\text { Farm } \\
\text { Non-Farm }\end{array}$ & $\begin{array}{r}8 \\
12\end{array}$ & $\begin{array}{l}24 \\
20\end{array}$ & $\begin{array}{l}24 \\
19\end{array}$ & $\begin{array}{l}3 \\
7\end{array}$ & $\begin{array}{l}4 \\
2\end{array}$ & $\begin{array}{l}4 \\
3\end{array}$ & $\begin{array}{r}6 \\
12\end{array}$ \\
\hline Rabbit & $\begin{array}{l}\text { Farm } \\
\text { Non-Farm }\end{array}$ & $\begin{array}{r}6 \\
13\end{array}$ & $\begin{array}{r}16 \\
9\end{array}$ & $\begin{array}{l}22 \\
20\end{array}$ & $\begin{array}{l}18 \\
15\end{array}$ & $\begin{array}{l}3 \\
2\end{array}$ & $\begin{array}{l}2 \\
3\end{array}$ & $\begin{array}{r}6 \\
13\end{array}$ \\
\hline $\begin{array}{l}\text { Ruffed } \\
\text { Grouse }\end{array}$ & $\begin{array}{l}\text { Farm } \\
\text { Non-Farm }\end{array}$ & $\begin{array}{l}0 \\
3\end{array}$ & $\begin{array}{l}5 \\
6\end{array}$ & $\begin{array}{l}16 \\
13\end{array}$ & $\begin{array}{l}16 \\
16\end{array}$ & $\begin{array}{l}9 \\
7\end{array}$ & $\begin{array}{l}18 \\
17\end{array}$ & $\begin{array}{r}9 \\
13\end{array}$ \\
\hline Deer & $\begin{array}{l}\text { Farm } \\
\text { Non-Farm }\end{array}$ & $\begin{array}{l}2 \\
1\end{array}$ & $\begin{array}{l}5 \\
8\end{array}$ & $\begin{array}{l}19 \\
27\end{array}$ & $\begin{array}{r}13 \\
8\end{array}$ & $\begin{array}{r}10 \\
7\end{array}$ & $\begin{array}{l}15 \\
11\end{array}$ & $\begin{array}{r}9 \\
13\end{array}$ \\
\hline $\begin{array}{l}\text { Wild } \\
\text { Turkey }\end{array}$ & $\begin{array}{l}\text { Farm } \\
\text { Non-Farm }\end{array}$ & $\begin{array}{l}0 \\
0\end{array}$ & $\begin{array}{l}0 \\
0\end{array}$ & $\begin{array}{l}0 \\
0\end{array}$ & $\begin{array}{l}0 \\
0\end{array}$ & $\begin{array}{l}0 \\
0\end{array}$ & $\begin{array}{l}64 \\
60\end{array}$ & $\begin{array}{r}9 \\
15\end{array}$ \\
\hline Quail & $\begin{array}{l}\text { Farm } \\
\text { Non-Farm }\end{array}$ & $\begin{array}{l}0 \\
2\end{array}$ & $\begin{array}{l}6 \\
6\end{array}$ & $\begin{array}{r}15 \\
8\end{array}$ & $\begin{array}{l}10 \\
14\end{array}$ & $\begin{array}{r}13 \\
4\end{array}$ & $\begin{array}{l}19 \\
25\end{array}$ & $\begin{array}{l}10 \\
16\end{array}$ \\
\hline Raccoon & $\begin{array}{l}\text { Farm } \\
\text { Non-Farm }\end{array}$ & $\begin{array}{r}5 \\
13\end{array}$ & $\begin{array}{l}17 \\
18\end{array}$ & $\begin{array}{l}22 \\
18\end{array}$ & $\begin{array}{l}9 \\
5\end{array}$ & $\begin{array}{l}3 \\
2\end{array}$ & $\begin{array}{l}8 \\
6\end{array}$ & $\begin{array}{r}9 \\
13\end{array}$ \\
\hline Bear & $\begin{array}{l}\text { Farm } \\
\text { Non-Farm }\end{array}$ & $\begin{array}{l}0 \\
0\end{array}$ & $\begin{array}{l}0 \\
0\end{array}$ & $\begin{array}{l}0 \\
0\end{array}$ & $\begin{array}{l}0 \\
0\end{array}$ & $\begin{array}{l}2 \\
0\end{array}$ & $\begin{array}{l}62 \\
61\end{array}$ & $\begin{array}{r}9 \\
14\end{array}$ \\
\hline Groundhog & $\begin{array}{l}\text { Farm } \\
\text { Non-Farm }\end{array}$ & $\begin{array}{l}30 \\
31 \\
\end{array}$ & $\begin{array}{l}22 \\
22 \\
\end{array}$ & $\begin{array}{r}10 \\
5\end{array}$ & $\begin{array}{l}3 \\
2\end{array}$ & $\begin{array}{l}0 \\
2\end{array}$ & $\begin{array}{l}0 \\
0\end{array}$ & $\begin{array}{r}8 \\
13\end{array}$ \\
\hline
\end{tabular}

Chi-Square Test of Farm and Non-Farm Evaluations

\begin{tabular}{lcc}
\hline Wildlife & $\begin{array}{c}\text { Theoretical Vaiue } \\
\text { of Chi-Square at } \\
\text { the 95\% Level }\end{array}$ & $\begin{array}{c}\text { Computed Value } \\
\text { of Chi-Square }\end{array}$ \\
\hline Squirrel & 12.592 & $6.04^{* * *}$ \\
Rabbit & 12.592 & $8.35^{* *}$ \\
Ruffed Grouse & 12.592 & $3.03^{* *}$ \\
Deer & 12.592 & $7.07^{* *}$ \\
Wild Turkey & 12.592 & $2.00^{* *}$ \\
Quail & 12.592 & $11.04^{* *}$ \\
Raccoon & 12.592 & $6.08^{* *}$ \\
Bear & 12.592 & $3.04^{* *}$ \\
Groundhog & 12.592 & $5.08^{* * *}$ \\
\hline
\end{tabular}

*The sample includes 73 landowners whose lands are being farmed and 75 landowners whose lands are not being farmed.

** No apparent difference between farm and non-farm evaluations. 

